\title{
Factors controlling landslide initiation as a result of July 2001 high-precipitation events in a section of the Lower New River Gorge, West Virginia
}

\author{
M. Patrick Kish \\ West Virginia University
}

Follow this and additional works at: https://researchrepository.wvu.edu/etd

\section{Recommended Citation \\ Kish, M. Patrick, "Factors controlling landslide initiation as a result of July 2001 high-precipitation events in a section of the Lower New River Gorge, West Virginia" (2004). Graduate Theses, Dissertations, and Problem Reports. 2043.}

https://researchrepository.wvu.edu/etd/2043

This Thesis is protected by copyright and/or related rights. It has been brought to you by the The Research Repository @ WVU with permission from the rights-holder(s). You are free to use this Thesis in any way that is permitted by the copyright and related rights legislation that applies to your use. For other uses you must obtain permission from the rights-holder(s) directly, unless additional rights are indicated by a Creative Commons license in the record and/ or on the work itself. This Thesis has been accepted for inclusion in WVU Graduate Theses, Dissertations, and Problem Reports collection by an authorized administrator of The Research Repository @ WVU. For more information, please contact researchrepository@mail.wvu.edu. 
FACTORS CONTROLLING LANDSLIDE INITIATION AS A RESULT OF JULY 2001 HIGH PRECIPITATION EVENTS IN A SECTION OF THE LOWER NEW RIVER GORGE, WEST VIRGINIA

\author{
M. Patrick Kish \\ Thesis Submitted to the \\ Eberly College of Arts and Sciences at \\ West Virginia University \\ In Partial Fulfillment of the Requirements for the Degree of \\ Master of Science \\ in \\ Geology \\ J. Steven Kite Ph.D., Chair \\ Robert E. Behling Ph.D. \\ Jeff Skousen Ph.D.
}

Department of Geology and Geography

Morgantown, West Virginia

2004

Keywords: Geology, West Virginia, New River Gorge, Landslides 


\section{Abstract \\ FACTORS CONTROLLING LANDSLIDE INTIATION AS A RESULT OF JULY 2001 HIGH PRECIPITATION EVENTS IN A SECTION OF THE LOWER NEW RIVER GORGE, WEST VIRGINIA}

\section{Patrick Kish}

Several geologic and physical factors affect the location of landslides associated with the July 2001 high precipitation events in Lower New River Gorge, West Virginia. The surficial geology of the heavily mined landscape was mapped using ArcGIS 8.3 and four specific factors related to the landslides were identified. Road building was shown statistically to have a positive influence on the location of landslides. Slope aspect, slope angles, and elevation were also shown to have strong relationships with landslide initiation.

A landslide initiation risk map was created by overlaying the physical and geological factors favorable for landslide initiation. The risk map outlines areas that may be prone to future slope instability as a result of the combination of land use activity, slope angles and slope geometry. It was determined that approximately $10 \%$ of the slopes of Lower New River Gorge are hazard prone. 


\section{Acknowledgements}

I would like to thank the many folks who were instrumental in helping me complete this thesis. I would like to first thank my wife Karen for her constant uplifting attitude and assistance in the field. On the technical side of things I would like to thank Andrew Steele of the National Park Service for all his insight and data pertaining to the July 2001 rain events. Mike Strager and the folks at the West Virginia GIS Technical Center were always there to answer my questions. I'd like to thank the members of my committee, Dr. Kite, Dr. Behling, and Dr. Skousen for patiently sticking with me and my thesis. Lastly, I'd like to thank the folks within the USGS EDMAP program for helping fund this thesis. 


\section{Table of Contents}

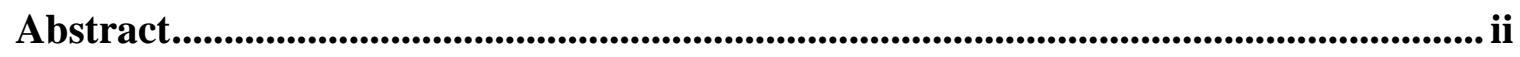

Acknowledgements ............................................................................................................. iii

List of Figures and Plates ................................................................................................

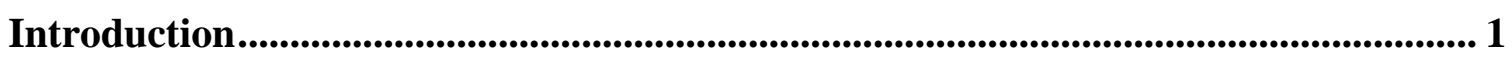

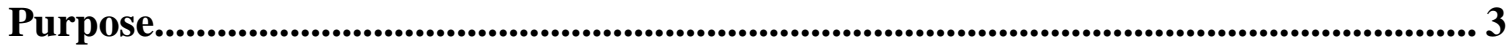

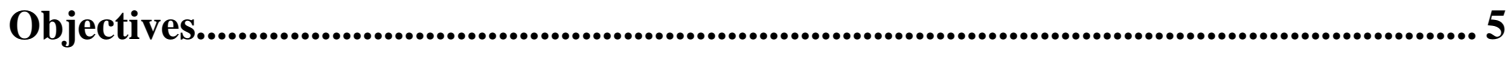

Study Area

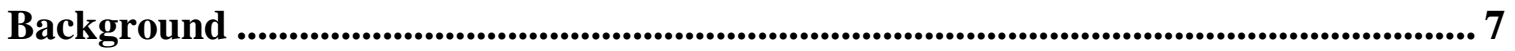

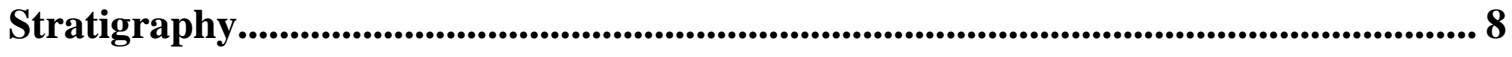

Surficial Geology ................................................................................................................... 11

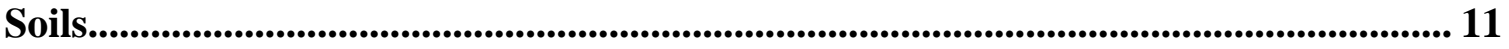

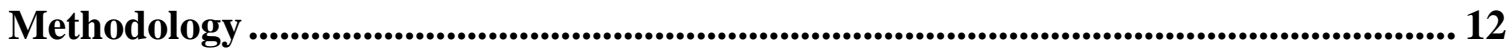

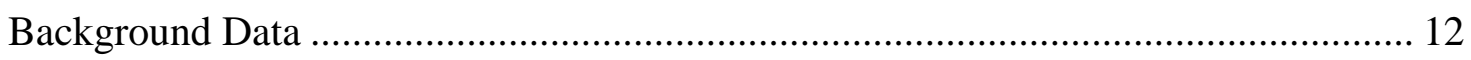

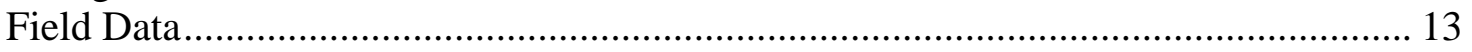

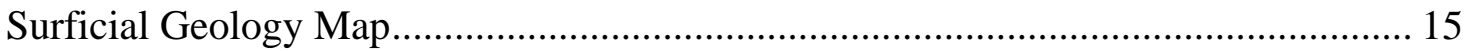

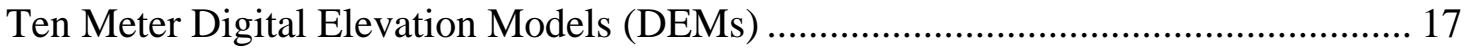

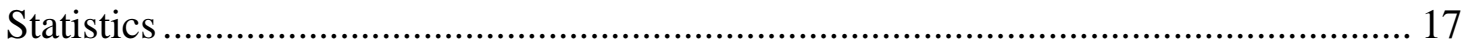

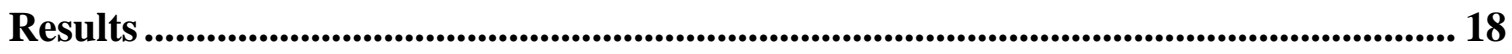

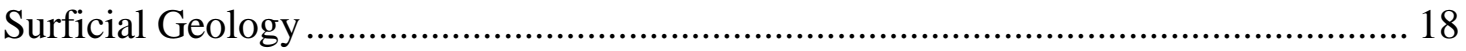

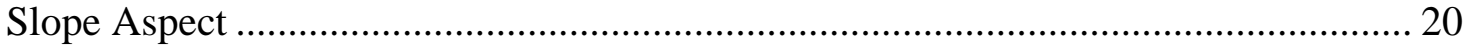

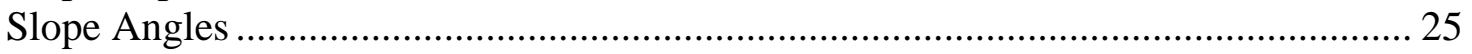

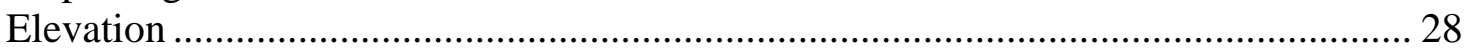

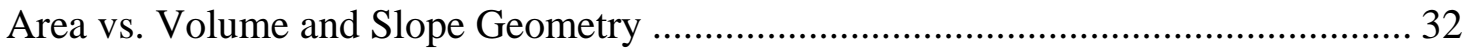

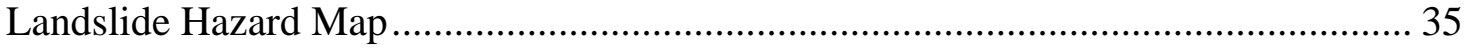

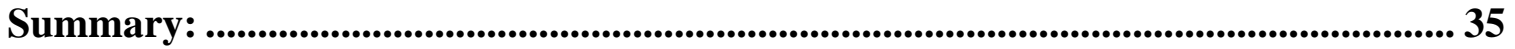

Discussion: ......................................................................................................................... 38

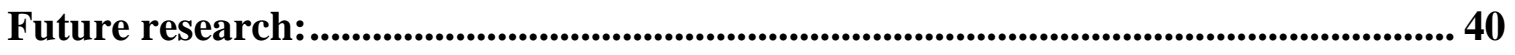

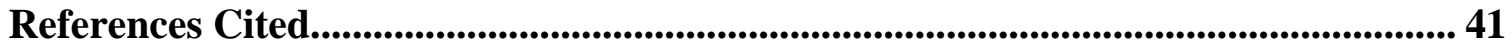




\section{List of Figures and Plates}

Figure 1: National Weather Service total storm precipitation for July 9, 2001 ................ 2

Figure 2: Flood waters inundated the former bank of Glen Jean ................................... 4

Figure 3: Lower New River Gorge, West Virginia, study area location map.................. 6

Figure 4: Pennsylvanian and Mississippian aged bedrock geology of the study area .......9

Figure 5: Stratigraphy of Lower New River Gorge study area.................................... 10

Figure 6: West Virginia University landslide inventory sheet................................... 14

Figure 7: Field measured slope aspect data plotted against DEM derived slope aspect. 23

Figure 8: Histogram comparing slope aspect of all July 2001 landslides to all slope aspects for the study area

Figure 9: DEM generated slope angles for landslides compared to total study area and field measured adjacent slope angles.

Figure 10: $\mathrm{X}-\mathrm{Y}$ scatter plot showing landslide area versus landslide volume..... 33

Figure 11: $\mathrm{X}-\mathrm{Y}$ plots showing landslide area versus landslide volume segregated by slope geometry

Figure 12: DEM field measured slopes compared to field measured adjacent slopes.

Future work comparing DEM generated slope angles and field measured slope angle is suggested as a result of the lack of correlation between these two data sets........37

Plate 1: Surficial Geology of a Section of the Lower New River Gorge,

West Virginia

Plate 2: Risk of Landslide Initiation and Runout in the Lower New River Gorge, West Virginia 


\section{List of Tables}

Table 1: Surficial geology units for Lower New River Gorge study area 16

Table 2: Chi-square goodness of fit table for landslide locations compared to surficial geology units

Table 3: Chi-square goodness of fit table for landslide locations compared to location of peripheral mine disturbance areas

Table 4: Chi-square goodness of fit table for landslide locations compared to the location of alluvium

Table 5: Chi-square goodness of fit table for landslide locations compared to mine spoil

Table 6: Chi-square goodness of fit table for landslide locations compared to colluvium

Table 7: Chi-square goodness of fit table for landslides associated with transportation networks within Lower New River Gorge.

Table 8: Chi-square goodness of fit table for landslide slope aspect compared to overall aspects in study area

Table 9: Table showing comparison of field measured slopes to DEM generated slopes for same locations

Table 10: Table showing DEM generated slope angles for field visited landslides locations compared to DEM generated slope angles for un-visited landslides

Table 11: DEM generated slope angles for all landslides compared to DEM generated slope angles for all study area

Table 12: Chi-square goodness of fit table for landslide elevations and total study area elevations subdivided into $20 \mathrm{~m}$ increments

Table 13: The chi-square goodness of fit test for landslide elevations and total study area elevations subdivided into $100 \mathrm{~m}$ increments 


\section{Introduction}

The rugged topography of the Appalachian Plateau is constantly being sculpted and reworked by weathering-processes, colluvial-processes, and fluvial-processes. In addition to these natural processes, the landscape in southern West Virginia has been altered by intensive coal mining. Prior to the Surface Mine Control and Reclamation Act (SMCRA) of 1977, the placement of mine spoil material along hillsides was not regulated (Skousen, 2001). Pre-SMCRA mining methods included contour-stripping techniques that resulted in over-steepened slopes, drainage disruption, and large amounts of oversteepened, un-consolidated mine spoil. The combinations of these processes and their effect on the extremely rugged topography of the southern West Virginia Coal fields result in mass-wasting events associated with heavy rainfall. An understanding of hillslope processes and characteristics in these areas is imperative when assessing the downslope and downstream safety of local inhabitants within areas prone to slope failures.

Two high precipitation events in July 2001 (July 8 and July26) resulted in numerous slope failures and extensive flooding in New River Gorge area (Figure 1). . The rainfall total at New River Gorge National Park headquarters in Glen Jean, Fayette County, West Virginia, on 8 July 2001 reached 114 millimeters (mm) over 4.5 hours and $279.4 \mathrm{~mm}$ at Upper Arbuckle Creek (National Park Service Resource Assessment Team, 2001). The data from Arbuckle Creek is questionable doe to the possibility of a malfunctioning rain gauge (per conversation with J.S. Kite, 2004). Severe flooding affected many tributaries of the New River including Arbuckle Creek, Coal Run, and Wolf Creek, all of which transported boulder-size bedload material. According to initial reports by the National Park Service (NPS), 70 to 80 slides and debris flows were visible from the air in the lower and middle gorge within the park immediately after the storm events (National Park Service Resource Assessment Team, 2001). Of 27 trails in the National Park, 14 were damaged by the heavy precipitation; trail washouts were common (National Park Service Resource Assessment Team, 2001). The Park headquarters had to be evacuated due to rising flood waters (National Park Service Resource Assessment Team, 2001). Flood waters damaged the former Bank of Glen Jean, which is listed on 


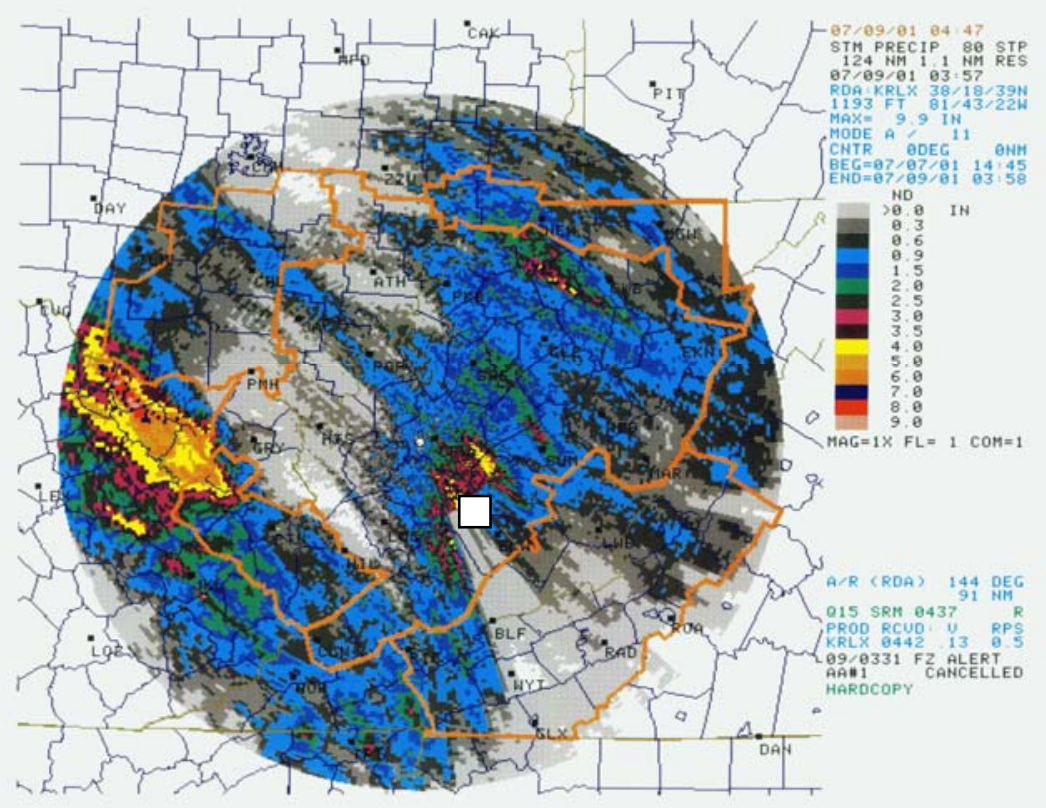

Figure 1: National Weather Service total storm precipitation for July 9, 2001 (National Oceanographic and Atmospheric Administration, 2002). White rectangle identifies general location of the study area. 
the National Register of Historic Places during the July 8 flooding event (National Park Service Resource Assessment Team, 2001) (Figure 2). Loss of life was averted during this event by a NPS rescue effort that saved two residents from being washed away from their home (National Park Service Resource Assessment Team, 2001). At the end of July 2001, 26 West Virginia counties, including Fayette, were declared federal disaster areas.

The July 26 event produced approximately $100 \mathrm{~mm}$ of rain in 5 hours over the same area as the July 8 storm (National Oceanographic and Atmospheric Administration, 2002). Once again, the park headquarters were flooded and required evacuation. Aerial reconnaissance by NPS staff identified several new and many reactivated slides in the gorge (National Park Service Resource Assessment Team, 2001). Six park facilities were damaged by flooding; trails, boat ramps, and retaining walls were impacted by debris flows as a result of the two storm events (National Park Service Resource Assessment Team, 2001). Located approximately 5 kilometers $(\mathrm{km})$ south of the gorge, the Oak Hill meteorological weather station recorded a +229 mm (170 \%) departure from normal precipitation for the month of July (National Oceanographic and Atmospheric Administration, 2002).

\section{Purpose}

The importance of rainfall intensity, soil texture, and soil thickness with respect to the occurrence of both debris flows and slides are of great interest to geomorphologists and engineering geologists. The desire for protection of life and property has spurred increased interest in the mechanisms involved with rapid mass movements. Wieczorek (1987) identified the importance of antecedent rainfall, soil thickness, hillslope concavity, and slope steepness in slope-failure initiation on steep, planar hillsides. Storms of short duration and high intensity (similar to the 8 July and 26 July event) can trigger debris flows on steep planar hillsides where shallow bedrock acts as a permeability barrier for infiltration, resulting in a build-up of high pore-water pressures. The slopes of New River Gorge present a geologic setting within the parameters set forth by Wieczorek (1987). It was the purpose of this study to evaluate the factors identified by Wieczorek and additional factors of management related activities; road construction and mining. 


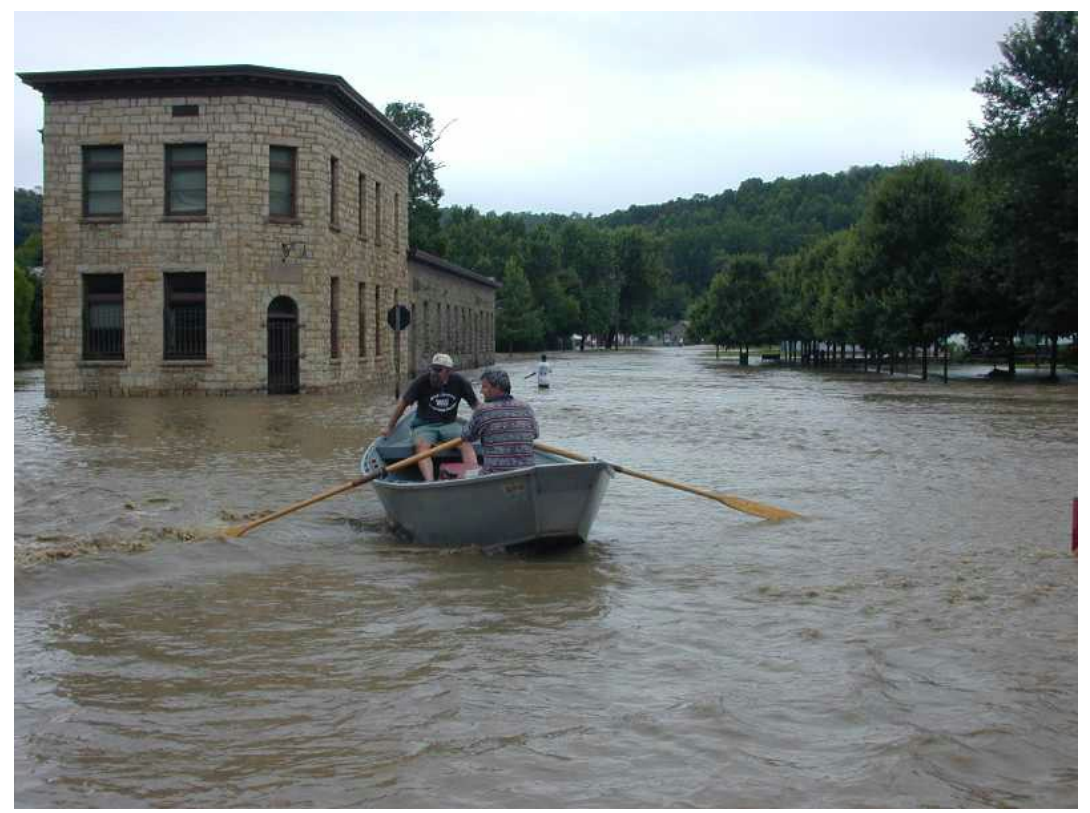

Figure 2: Flood waters inundated the former bank of Glen Jean, which is listed on the National Register of Historic Places (National Park Service photo, 2001). 


\section{Objectives}

Work pertaining to recent and historical slope failures has been completed within the study area by Remo (1999), Moore (1999), and Kwak (2002). The economic and archaeological impact of landslides and floods has raised questions as to future prediction and remediation of high-risk areas in the gorge. At the present time the NPS does not evaluate trail repair issues based on slope stability. Economically, it would be advantageous to identify areas within the gorge that are at a higher risk of future landslide initiation, allowing money invested in trail reconstruction to be more wisely allotted towards lower risk areas. The recognition of environmental variables associated with landslides and flooding in the gorge may play an integral part in any comprehensive land management plans set forth by the NPS.

The primary goal of this thesis was to identify areas in the gorge that are susceptible to mass movements as a result of prior land-use activities. Another goal was to show that certain areas of the gorge are at higher risk for landslide initiation. If mechanisms that initiated the July 2001 landslides were better understood, the future prediction of economic loss or loss of human life could be made. Once high risk areas are pinpointed, remediation measures can be undertaken to lessen the risk of future landslides or warnings can be made to nearby neighbors. The information from this thesis was used to produce a landslide initiation and runout risk map (Plate 2) that outlines areas of the gorge prone to repeated landslides. Potential landslide runout paths were also mapped. This map was produced by analyzing the interactions of several variables including slope angle, slope aspect, surficial geology, elevation, and slope geometry. The results of this study may help the NPS to better understand geologic factors involved in slope stability within the gorge.

\section{Study Area}

The study area for this thesis was located within the boundaries of New River Gorge National Scenic River in Fayette County, West Virginia (Figure 3). All of the work was completed from the town of Thurmond downstream (northward) to the U.S. 


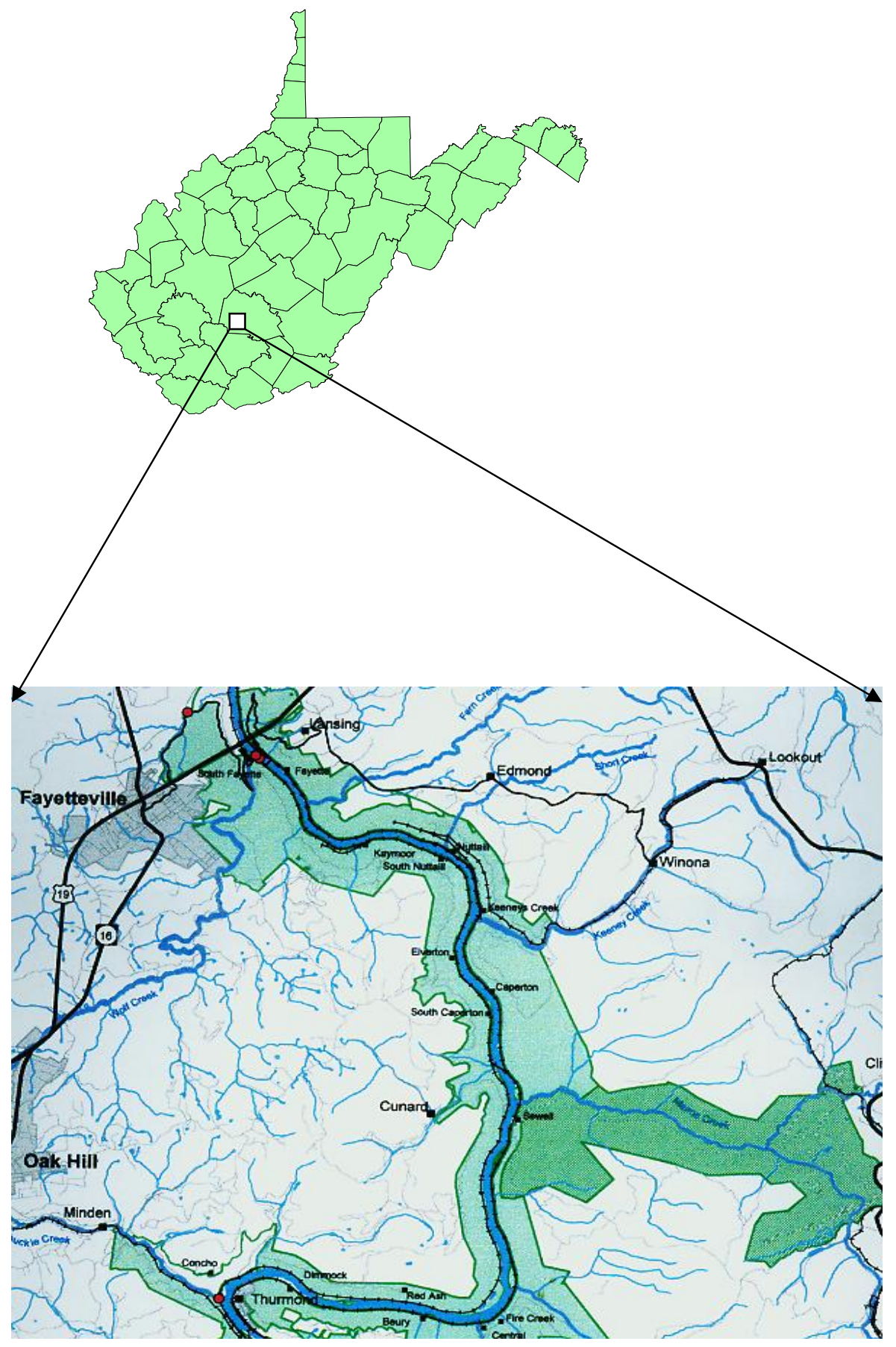

Figure 3: Lower New River Gorge, West Virginia, study area location map. (Modified from National Park Service Resource Assessment Team, 2001) 
Route 19 Bridge near Fayette Station: approximately 8 straight-line km and 15 river km apart.

\section{Background}

New River is commonly referred to as one of the oldest rivers in the world (Morgan and Mayfield, 1994). New River is thought by some to have originated in the Mesozoic Era, when it acted as the headwaters for the ancient westward flowing Teays River system, and has remained more or less on its present course since the Jurassic Period (140 ma) (Morgan and Mayfield, 1994). Although no conclusive evidence is available to prove or refute these age claims, the $547 \mathrm{~km}$ long river has incised an impressive gorge through the Appalachian Plateau's. The maximum depth of the gorge is about 500m just north of Hinton (Mills, 1990). The $106 \mathrm{~km}$ stretch of river from Hinton, West Virginia to Gauley Bridge, West Virginia, has a gradient of approximately 0.002.

The low-sulfur coal in New River Gorge was heavily mined in the late 1800's to middle 1900’s. Mining techniques included underground and strip mining and resulted in large portions of the gorge being disturbed. One of the first mines in the study area was the Sewell Top Mine, established in 1873 just south of Mann’s Creek (Lane and Schnepf, 1999).

New River flows northwest from its headwaters in North Carolina to Gauley Bridge, West Virginia, where it merges with the Gauley River, where the river is renamed the Kanawha River. The average discharge of New River as measured at the Hinton USGS gauging station is $224 \mathrm{~m}^{3} / \mathrm{s}$ (Ward et al., 1999). The highest gauged flow at Hinton was 6,967 m³ s and occurred as a result of a hurricane in 1940 (Ward et al., 1999). A flow of this magnitude is unlikely in the future due to runoff storage upstream behind the Bluestone Dam, completed in 1949 (National Park Service Resource Assessment Team, 2001).

The climate of the middle and upper gorge produces average mean rainfall totals between 1140 and 1170 mm/yr (Gorman and Espy, 1975). Flash flooding of small streams in New River Gorge results from intense widespread rainfall and is generally not attributed to the gradual spring snow pack melt (Gorman and Espy, 1975).

On 10 November 1978, 85 km of New River Gorge between Hinton and Fayetteville were designated as a National Scenic River, “for the purpose of conserving 
and interpreting outstanding natural, scenic, and historic values and objects in and around New River Gorge and preserving as a free-flowing stream an important segment of New River in West Virginia for the benefit and enjoyment of present and future generations (National Park Service Resource Assessment Team, 2001). The designation resulted in approximately 28,300 hectares of National parkland.

\section{Stratigraphy}

Four major stratigraphic units occur within the study area and have a regional dip of less than $2^{\circ}$ to the northwest (Englund et al., 1977) (Figure 4 and 5). The upper three lie within the Pennsylvanian Pottsville Group: the Kanawha, New River, and Pocahontas formations. The oldest formation in the study area is the Bluestone Formation within the uppermost Mississippian Mauch Chunk Group (Englund et al., 1977).

The Kanawha Formation is approximately $90 \mathrm{~m}$ thick and is the uppermost bedrock unit within the study area (Figure 4 and 5). It is comprised mainly (65\%) of easily weathered siltstone and shale (Englund et al., 1977). This formation contains the Gilbert and Eagle coal seams which were not mined within the study area.

The New River Formation occurs immediately below the Kanwaha Formation (Figure 4 and 5). This extremely resistant unit is dominated by sandstone (50 to $60 \%$ ), with lesser amounts siltstone, shale, coal, and fireclay. The New River Formation ranges between 215 and $305 \mathrm{~m}$ in thickness and contains the upper and lower Nuttall sandstones, which act as the resistant capstone within the study area (Englund et al., 1977). Coal from the New River Formation has been extensively mined within the study area, most notably the Sewell coal bed (Figure 5). The Fire Creek coal is stratigraphically lower than the Sewell coal and was mined within the study area, but not as extensively. The New River Formation unconformably lies over the Pocahontas Formation.

The 130 m thick Pocahontas Formation is largely comprised of sandstone (70 \%) and shale (28 \%) with minor amounts of coal and fireclay (Englund et al., 1977) (Figure 4 and 5). The Pocahontas coal seams are located within this formation, but are not within the study area.

The Pennsylvanian Bluestone Formation is located at river level at the southern extent of the study area (Figure 4 and 5). The Bluestone consists of shale and siltstone 


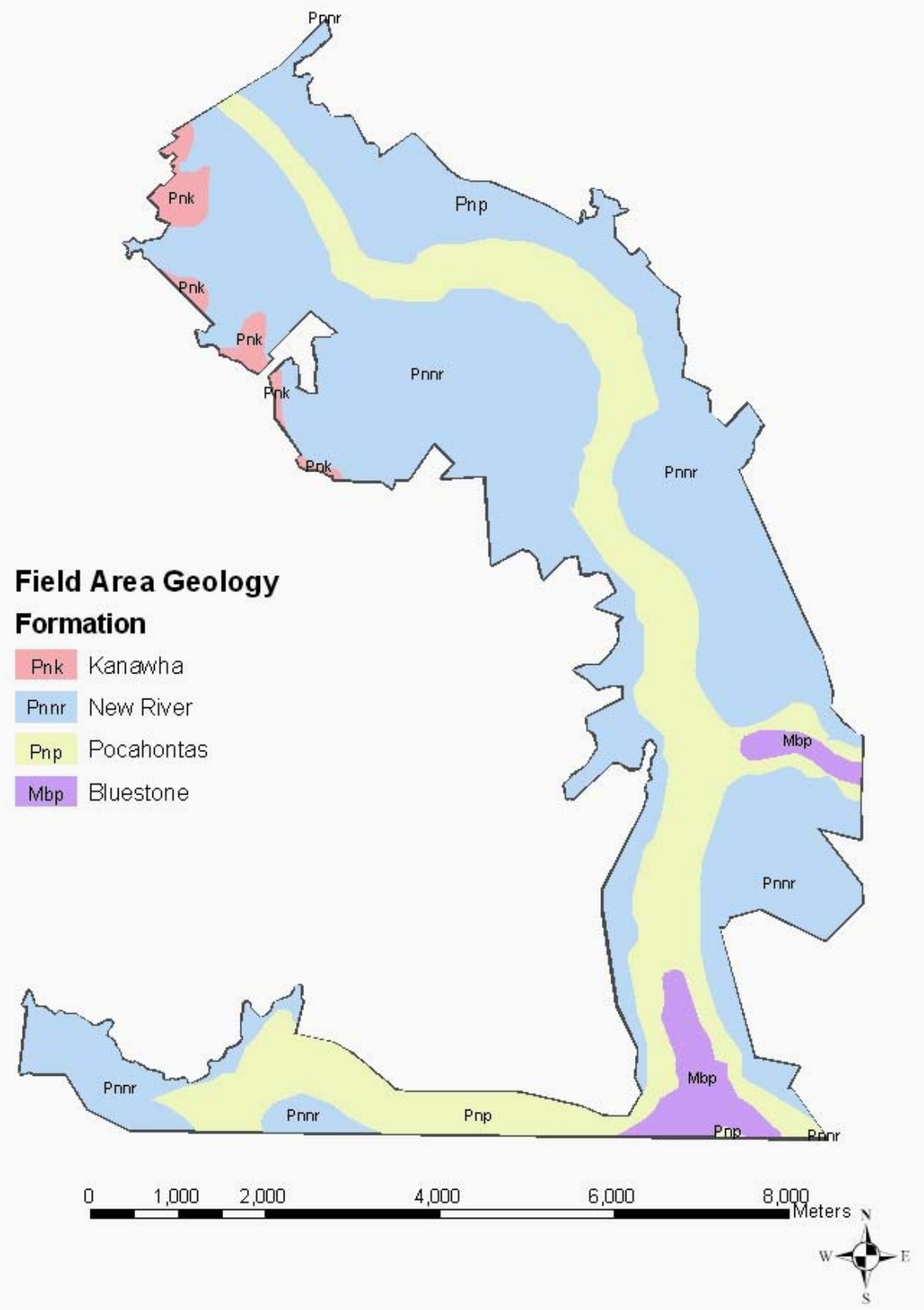

Figure 4: Pennsylvanian and Mississippian aged bedrock geology of the study area in Lower New River Gorge National Scenic River. (Modified from Englund et al, 1977) 


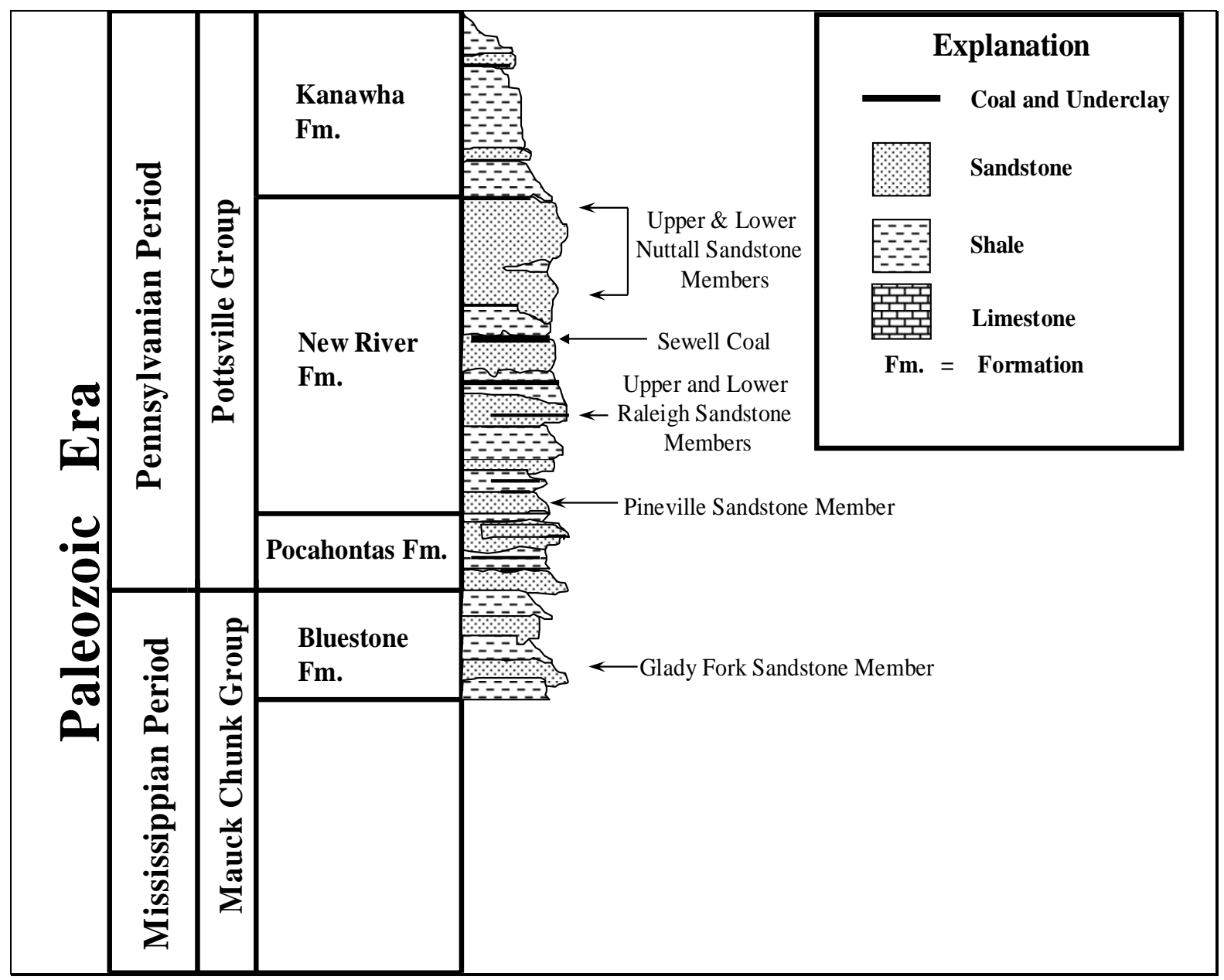

Figure 5: Stratigraphy of Lower New River Gorge study area. Stratigraphic column's not to scale. (Modified from Remo, 1999, and Englund et al., 1977 
with minor amounts of sandstone and limestone, but no mineable coal seams occur within this unit in the study area.

\section{Surficial Geology}

The surficial deposits of Lower New River Gorge are dominated by colluvium (Remo, 1999). Small areas of residuum occur above the rim of the gorge and result from the in-situ weathering of the upper Nuttall sandstone and overlying units (Remo, 1999). Small areas of alluvium occur at the base of the gorge adjacent to New River and its larger tributaries (Moore, 1999). The remainder of the surficial deposits can be attributed to land use practices including years of coal mining throughout the gorge (Yuill, 1988).

The topography of the lower gorge consists of planar slopes, hollows, and nose slopes (Moore, 1999). Planar slopes are areas in which topographic contours continue straight across the slope (Hack and Goodlett, 1960). Nose slopes are delineated by convex contour lines (Hack and Goodlett, 1960). Nose slopes tend to be the driest slope landform because runoff tends to diverge as it moves downslope (Moore, 1999). Hollows are sites of colluvium accumulation and subsurface water concentration (Kochel, 1987), resulting in an increased risk of debris-flow initiation during high precipitation events (Hack and Goodlett, 1960).

\section{Soils}

Soils within the study area consist of residual material, gravity transported material, water transported material and anthropogenically transported material (Gorman and Espy, 1975).

- Residual soils located above the rim of the gorge are classified as Dekalb fine, sandy loams that occur and gentle slopes (10-20\%).

- Soils directly below the rim of the gorge generally fall within Steep rock land which includes rough, broken sandstone cliffs and rock outcrops on uplands. This land is most extensive in the gorge (Gorman and Espy, 1975).

- Dekalb-Gilpin very stony soils located downslope from the rim are moderately deep, well-drained soils having moderately coarse to medium textures and occurring on very steep slopes (40-70\%). 
- Soils directly adjacent to New River and at the footslope of the gorge have been mapped as the Ernest and Shelocta very stony silt loams, moderately deep, welldrained, and moderately coarse to medium textured on moderate slopes (20-40\%).

- Strip-mine spoil consists of overburden material left upon the surface as a result of surface coal mining and accounts for approximately 10 to $15 \%$ of the total area within Fayette County

- Mine-refuse soils were produced during underground mining activity and are generally less voluminous than the mine spoil (Yuill, 1988).

The mine-refuse soils and strip-mine spoil generally follow the Sewell coal seam throughout the study area, although significant refuse and spoil are associated with other coal seams within the gorge. Updated soil mapping and re-naming of soils within the field area will be taking place in the near future (Jenkins, 2002).

\section{Methodology}

The data collection and organization for this thesis entailed several different stages. First, background information dealing with New River Gorge was collected in the form of historical aerial photos, digital data, and regional maps. Second, after landslide data sheets were created, intensive fieldwork occurred between March 2002 and August 2003. Finally, data collected during fieldwork and various other sources were then entered into Microsoft Excel and ArcGIS 8.3 for data management and analysis. The combination of the data collection and organization phases resulted in a data set suitable for final analysis.

\section{Background Data}

Background information was collected from several different sources. Bedrock geology was obtained from geologic maps by Englund et al. (1977). In the summer of 2003, aerial photos from 1957 and 1970 were viewed stereoscopically to assist in mapping historically disturbed areas. The heavily mined landscape made it difficult to delineate denuded landscape resulting from landslides versus that associated with mining. Possible slide locations were transferred to the Fayetteville or Thurmond topographic quadrangles and an attempt to visit each of these locations was made during fieldwork. In the summer and fall of 2003, aerial photographs from 1957 provided by the West 
Virginia Geologic and Economic Society (WVGES) were reviewed in a similar fashion. Historic photographs provided by the West Virginia Collection section of the West Virginia University main library and Lane and Schempf (1999) were used to help reconstruct the cultural history. Several attempts to contact the CSX Corporation failed to attain documentation detailing slide-damaged tracks located within the gorge.

Aerial photography that would have been useful for this thesis was scheduled to be flown in the spring of 2002. Miscommunication between the NPS and their contractor resulted in the photography being delayed until the spring of 2003 (Steele, 2003).

Therefore, landslides associated with the July 2001 rain events could not be mapped with the use of aerial photographs. The 2003 air photo mosaic for the park is currently available through the NPS. This mosaic was not obtained until fall 2004 and, thus, was not utilized for this thesis.

The landslides that occurred as a result of the July 8 event were captured using an handheld GPS unit from a helicopter on days following the rain events. On July 11 and July 24, NPS GIS Technician Andrew Steel captured approximately 80 landslide coordinates from the air. Several of the large landslides had multiple GPS points associated with them in an attempt to show their full spatial extent. A total of 36 NPS landslide points were used during analyses. An additional 17 NPS landslide coordinates were located during field work.

\section{Field Data}

Landslide data were gathered during visits to the study area between March 2002 and August 2003. Thirty-one landslides were visited, Global Positioning System (GPS) point locations were acquired, and landslide inventory sheets were completed (Figure 6). Field identified landslide locations overlapped with 17 NPS GPS coordinates indicating a generally good match between the two data sets. The types of failures were determined using field evidence and guidelines described in Campbell et al. (1985) and Hungr et al. (2001). Detailed cross sections of the headscarp areas were performed in the field in order to determine area, volume, slope, and aspect associated with the each visited landslide. Volumetric estimates of the material mobilized were determined by length, width, and depth measurements (from vertical faces within the scarp) from the source 


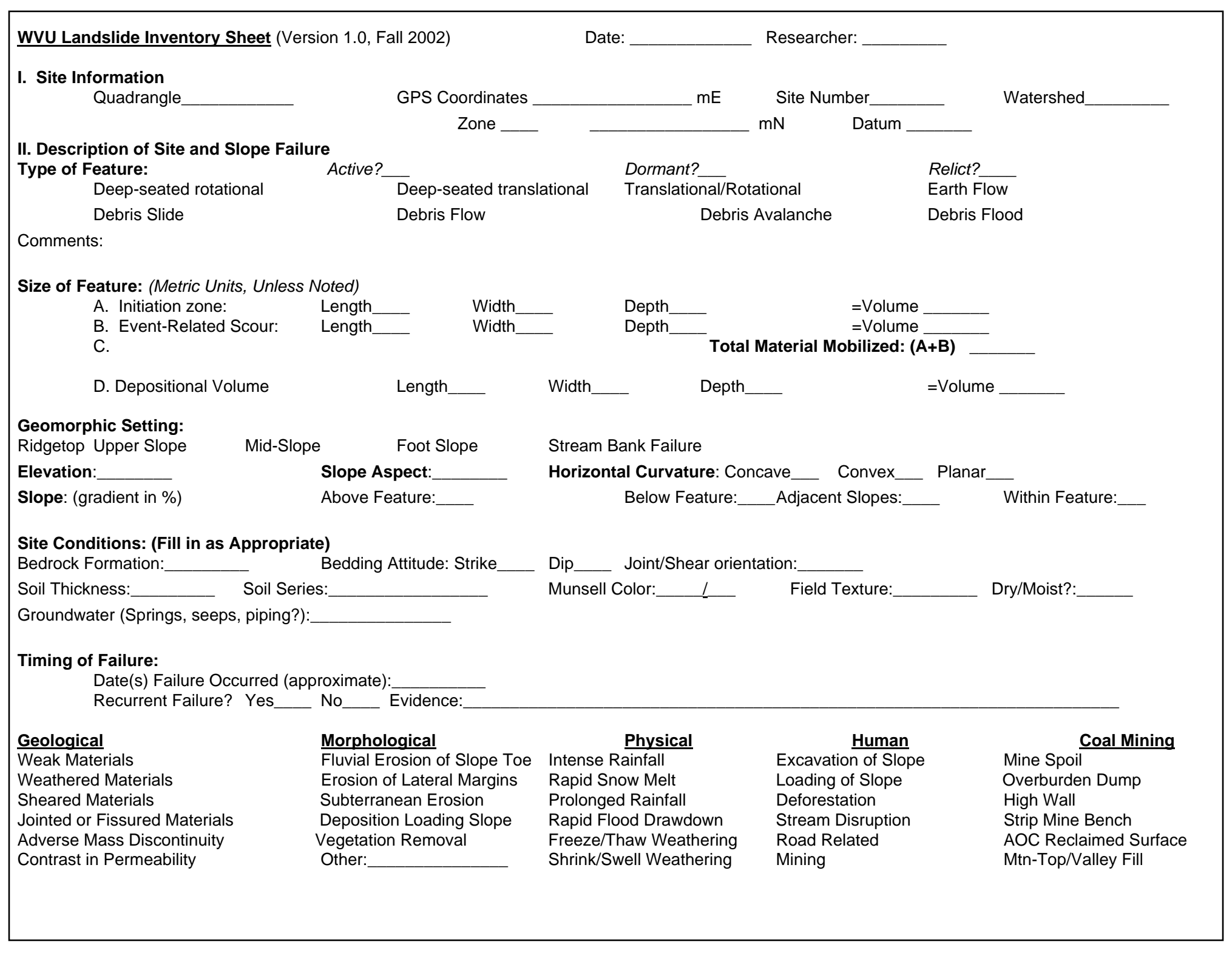

Figure 6: West Virginia University landslide inventory sheet developed by M. Patrick Kish and J. Steven Kite, 2002. 
area using a 100-meter tape. Slope gradients above, below, and directly adjacent to each landslide were measured using a handheld Suunto inclinometer; horizontal slope geometry was noted in the field. Slope aspect for hillsides directly associated with each landslide was measured in degrees using a Suunto compass. A handheld Garmin 12 XL GPS unit was used to collect location data in the field, generally within + or -10 m accuracy. Photographs of landslides were taken to supplement field descriptions.

Digital data in the form of Geographic Information Systems (GIS) shapefiles were obtained from the NPS New River Gorge GIS Center. These data included updated park boundaries, transportation networks within the park, and GPS positions of some July 2001 landslide locations. The GPS points had been taken by NPS Technician Andrew Steele on two separate dates, 11 July 2001 and 24 July 2001, in a helicopter using handheld Garmin GPS unit. Many landslides associated with the July 2001 event were located through the use of these points. GPS points recorded by Dr. Steven Kite during several visits to the gorge after July 2001 were collected and imported in to ArcGIS for analysis. Landslide data involving location and volumetric estimates in Kwak (2002) were added to digital data for the July 2001 events. Although the lack of post July 2001 aerial photographs initially hampered efforts to identify and locate landslides, abundant GPS location data available through several outlets made identification possible.

\section{Surficial Geology Map}

A surficial geology map of the study area was produced at a scale of 1:15,000 (Plate1) using ArcGIS 8.3. Only landslide initiation zones with area greater the $10 \mathrm{~m}^{2}$ were taken into consideration during mapping. The map contains several commonly used surficial geology mapping units along with several map units designed for heavily mined landscapes (Yuill, 1988; Kite, 2001) (Table 1).

Data used for generation of the surficial geology map were derived from fieldwork and existing maps for the area. Map units for the mined landscape where developed with the help of mine and well inventory maps produced for the area by Yuill (1988). These maps outlined several mined landscape features including mine boundaries, spoil and refuse locations, and mining highwalls. ArcGIS shapefiles were produced using heads up digitizing of the map units from Yuill (1988) and field data. All 


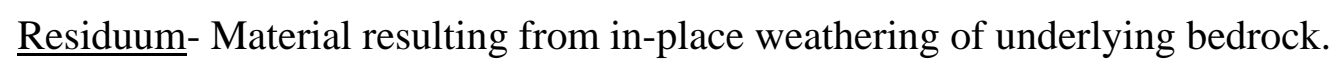

Colluvium- Unconsolidated rock and soil transported downslope as a direct result of gravity.

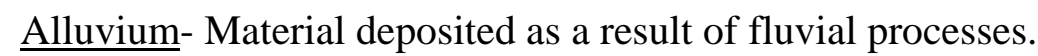

Transportation Network- Material that has been disturbed by road building.

Bedrock outcrops- Very resistant sandstone that results in vertical outcrop faces. Primarily the upper and lower Nuttall sandstone of the New River Formation.

Mine spoil- Material resulting from surface mining. Mine spoil material is generally poorly sorted (well-graded) material in which texture is related to the lithology of local bedrock.

Mine refuse- Waste material resulting from underground mine. Mine refuse is associated with discrete mine openings and typically is more geographically concentrated than mine spoil.

Peripheral Mine Disturbance- Areas that are not directly adjacent to coal seams but define the spatial extent of disturbance due to coal mining activities. This unit does not include mine spoil or mine refuse but may totally surround them.

Highwalls- Linear, nearly vertical slopes produced by overburden removal during surface mining.

Table 1: Surficial geology units for Lower New River Gorge study area. 
of the ArcGIS data (surficial geology units, landslide locations and transportation networks) were compiled to produce the final surficial geology map.

\section{Ten Meter Digital Elevation Models (DEMs)}

The 10 meter DEMs used for analysis were obtained for New River Gorge study area through the West Virginia GIS Technical Center (www.wvgis.wvu.edu). The 7.5 minute DEM data contain $10 \mathrm{~m}$ square pixels that are digital representations of topographic information in raster form. DEMs contain locational data, elevations, slope aspects, and slope angles. All data used for the analysis are Universal Trans Mercator (UTM) coordinate system in zone 17, referenced to North American Datum 1983.

\section{Statistics}

Landslide data were compiled in 14 Excel worksheets for further data reduction and statistical tests. X-Y scatter plots were constructed in Excel to show relationships between landslide variables: slope angle, slope aspect, slope geometry, and elevation.

Excel was used to calculate $r^{2}$ values for linear and polynomial trendlines. The $r^{2}$ value is coefficient of determination, which is useful in estimating the strength of the linear relationship between two variables (Weimer, 1993). Bar graphs and pie charts were constructed in Excel to show differences in the landslide data.

The chi-square (goodness of fit) test was performed on several data subsets to show relationships between expected and observed variables (Weimer, 1993). The following equation for chi-square was used:

$$
\mathrm{X}^{2}=\Sigma\left[(\text { Observed }- \text { Expected })^{2} / \text { Expected }\right]
$$

An independent two-sample t-test was used to compare sample means from independent populations (indicated below by the subscript 1 or 2), such as field data and DEM generated data (Weimer, 1993). The following equation was used for the t-test:

$$
\mathrm{t}=\left(\mathrm{X}_{1}-\mathrm{X}_{2}\right) / \text { sqrt } \mathrm{o}_{1} / \mathrm{n}_{1}+\text { sqrt } \mathrm{o}_{2} / \mathrm{n}_{2}
$$

where:

$$
\begin{aligned}
& \mathrm{X}=\text { population mean } \\
& \mathrm{o}=\text { sample standard deviation } \\
& \mathrm{n}=\text { sample size }
\end{aligned}
$$




\section{Results}

Analyses were performed upon data collected in the field, data previously collected from various sources, data generated from the surficial geology map, and data generated from GIS digital elevation models (DEMs). Landslide data were compiled into groups based on completeness of data.

The first group consisted of landslide data generated primarily from field observations. Field-visited landslide sites allowed more complete evaluation of site specifics and landslide characteristics such as landslide lengths, widths, and depths. Data compiled during field visits to 29 landslide locations, combined with data collected from Kwak (2002) and Kite (unpublished data), resulted in a total of 36 landslides in the first population.

Data in the second population were derived from GPS coordinates of landslides not visited in the field. Geographic coordinate data received from the NPS and Kite (unpublished data) were analyzed spatially with ArcGIS 8.3 to produce a digitally derived data set of 34 more locations. The amount of data derived digitally is less than that available from fieldwork, but the $10 \mathrm{~m}$ DEM were utilized to generate slope gradient, slope aspect, and elevation. The combined landslide data consists of 70 individual landslide points that were used for analysis.

\section{Surficial Geology}

The surficial geology map (Plate 1) for the Lower New River Gorge was used to test whether certain surficial units are prone to landslide initiation. The areas covered by each surficial geology unit and the percentage of each surficial unit within the gorge were calculated using ArcGIS. The percentages of the individual surficial geology units were compared to the total number of landslides to calculate an expected number of landslides for each surficial geology unit. A series of chi-square goodness of fit tests were performed on the surficial geology and landslide location data. The first chi-square test compared the randomness of landslide locations for all surficial geology units (Table 2). The null hypothesis for this test states that there was randomness in landslide locations with respect to the surficial geology. The null hypothesis was rejected at a significance level of 0.005 , indicating landslide locations were not randomly distributed with respect 


\begin{tabular}{|l|c|c|c|c|c|c|c|}
\cline { 2 - 7 } \multicolumn{1}{c|}{} & $\begin{array}{c}\text { Peripheral Mine } \\
\text { Disturbance }\end{array}$ & Colluvium & $\begin{array}{c}\text { Lower } \\
\text { New }\end{array}$ & $\begin{array}{c}\text { Mine } \\
\text { Refuse }\end{array}$ & $\begin{array}{c}\text { Mine } \\
\text { Spoil }\end{array}$ & $\begin{array}{c}\text { Residuu } \\
\mathbf{m}\end{array}$ & Alluvium \\
\hline $\begin{array}{l}\text { Number of Expected } \\
\text { Landslides }\end{array}$ & 11.54 & 32.26 & 3.69 & 0.33 & 1.89 & 17.98 & 2.29 \\
\hline $\begin{array}{l}\text { Number of Observed } \\
\text { Landslides }\end{array}$ & 16 & 45 & 0 & 0 & 8 & 0 & 1 \\
\hline
\end{tabular}

Chi-Square Calculation for Landslides and Surficial Geology

\begin{tabular}{|l|c|}
\hline $\begin{array}{l}\text { Degrees of } \\
\text { Freedom }\end{array}$ & 6 \\
\hline Chi-square value & 47.81 \\
\hline Significance level & 0.005 \\
\hline Critical Value & 18.55 \\
\hline Null Hypothesis & Reject \\
\hline
\end{tabular}

Table 2: Chi-square goodness of fit table for landslide locations compared to surficial geology units. The null hypothesis stating that landslide locations were randomly distributed with respect to surficial geology units was rejected at a 99.5\% confidence interval. The observed number of landslides indicated that the peripheral mine disturbance. colluvium. and mine 
to surficial geology.

A chi-square analysis was run for each individual surficial geology unit that was associated with at least one landslide. The null hypotheses for these tests were that landslide locations may be randomly associated with respect to surficial geology. The null hypotheses were not rejected at the .005 significance for the peripheral mine disturbance zones (Table 3) and alluvium (Table 4) surficial geology units. These results indicate that the landslides are randomly distributed with respect to these surficial geology units. The null hypothesis was rejected at the 0.005 significance level for the mine spoil (Table 5) and colluvium (Table 6) surficial units. Landslides were statistically shown to be preferentially initiated within the colluvium and mine spoil surficial units. The transportation network includes road and trails and covers a small (6\%) portion the study area. Of the landslides used in this study, 46 of the 70 originated on or adjacent to the transportation network. A chi-square goodness of fit test had a null hypothesis that there was a random spatial association between landslide locations and the transportation networks (Table 7). The null hypothesis was rejected using a confidence interval of 0.005. The chi-square analyses for each of the surficial geology units suggest that transportation networks were the most important surficial unit for determining landslide sites associated with the July 2001 storm events.

\section{Slope Aspect}

Slope aspect data derived during field visits were plotted against DEM-generated aspect data for the same locations $(n=29)$ on an XY scatter plot using Microsoft Excel (Figure 7). The $r^{2}$ coefficient was 0.9715 , showing a strong linear relationship between slope aspects measured in the field and DEM generated slope aspects for the same locations. These results support the hypothesis that the slope aspects associated with the 41 landslides without slope aspect data could be accurately derived using DEMs.

Slope aspects were divided up in to 8 groups for analysis: north $\left(327.5^{\circ}-22.5^{\circ}\right)$, northeast $\left(22.5^{\circ}-67.5^{\circ}\right)$, west $\left(67.5^{\circ}-112.5^{\circ}\right)$, southeast $\left(112.5^{\circ}-157.5^{\circ}\right)$, south $\left(157.5^{\circ}\right.$ $\left.202.5^{\circ}\right)$, southwest $\left(202.5^{\circ}-247.5^{\circ}\right)$, west $\left(247.5^{\circ}-292.5^{\circ}\right)$, and northwest $\left(292.5^{\circ}-327.5^{\circ}\right)$. DEM-generated slope aspects for all 70 landslide locations were calculated (Figure 8), showing that landslide initiation zones are preferentially located on eastern facing slopes, 


\begin{tabular}{|l|l|c|}
\hline & \multicolumn{1}{|c|}{$\begin{array}{c}\text { Peripheral Mine } \\
\text { Disturbance }\end{array}$} & $\begin{array}{c}\text { Sites Outside of } \\
\text { Peripheral Mine } \\
\text { Disturbance }\end{array}$ \\
\hline $\begin{array}{l}\text { Number of Expected } \\
\text { Landslides }\end{array}$ & 11.54 & \\
\hline \multirow{2}{*}{$\begin{array}{l}\text { Number of Observed } \\
\text { Landslides }\end{array}$} & 16 & 58.46 \\
\hline \multirow{2}{*}{ Chi-Square Calculation for Landslides and Mine boundaries } \\
\hline & $\begin{array}{l}\text { Degrees of } \\
\text { Freedom }\end{array}$ \\
\cline { 2 - 3 } & Chi-square value & 1 \\
\cline { 2 - 3 } & Significance level & 2.07 \\
\cline { 2 - 3 } & Critical Value & 0.005 \\
\cline { 2 - 3 } & Null Hypothesis & 7.88 \\
\cline { 2 - 3 } & \multicolumn{2}{|c|}{ Failure to reject } \\
\hline
\end{tabular}

Table 3: Chi-square goodness of fit table for landslide locations compared to location of peripheral mine disturbance areas. The null hypothesis that landslide locations were random with respect to mine boundaries could not be rejected at a $99.5 \%$ confidence level. July 2001 landslides did not preferentially initiate within peripheral mine disturbance areas.

\begin{tabular}{|l|l|c|}
\cline { 2 - 3 } \multicolumn{1}{c|}{} & Alluvium & non- alluvium \\
\hline $\begin{array}{l}\text { Number of Expected } \\
\text { Landslides }\end{array}$ & \multicolumn{1}{|c|}{2.29} & 67.71 \\
\hline $\begin{array}{l}\text { Number of Observed } \\
\text { Landslides }\end{array}$ & 1 & 69 \\
\hline \multirow{2}{*}{ Chi-Square Calculation for Landslides and Alluvium } \\
\hline & $\begin{array}{l}\text { Degrees of } \\
\text { Freedom }\end{array}$ \\
\cline { 2 - 3 } & Chi-square value & 1 \\
\cline { 2 - 3 } & Significance level & 0.75 \\
\cline { 2 - 3 } & Critical Value & 0.005 \\
\cline { 2 - 3 } & Null Hypothesis & 7.88 \\
\cline { 2 - 3 } &
\end{tabular}

Table 4: Chi-square goodness of fit table for landslide locations compared to the location of alluvium. The null hypothesis that landslide locations were random with respect to alluvium could not be rejected at a 99.5\% confidence level. July 2001 landslides did not preferentially initiate within alluvium. 


\begin{tabular}{|l|c|c|}
\cline { 2 - 3 } \multicolumn{1}{c|}{} & \multicolumn{1}{c|}{ Mine Spoil } & Non-Mine Spoil \\
\hline $\begin{array}{l}\text { Number of Expected } \\
\text { Landslides }\end{array}$ & 1.89 & 68.11 \\
\hline $\begin{array}{l}\text { Number of Observed } \\
\text { Landslides }\end{array}$ & \multicolumn{1}{|c|}{62} \\
\hline \multicolumn{2}{|c|}{} \\
\hline Chi-Square Calculation for Landslides and Mine Spoil \\
\hline & $\begin{array}{l}\text { Degrees of } \\
\text { Freedom }\end{array}$ & 1 \\
\cline { 2 - 3 } & Chi-square value & 20.3 \\
\cline { 2 - 3 } & Significance level & 0.005 \\
\cline { 2 - 3 } & Critical Value & 7.879 \\
\cline { 2 - 3 } & Null Hypothesis & Reject \\
\cline { 2 - 3 } &
\end{tabular}

Table 5: Chi-square goodness of fit table for landslide locations compared to mine spoil. The null hypothesis that landslide locations were random with respect to mine spoil can be rejected at a 99.5\% confidence level. July 2001 landslides preferentially initiated in mine spoil.

\begin{tabular}{|l|l|c|}
\cline { 2 - 3 } \multicolumn{1}{c|}{} & Colluvium & Non-Colluvium \\
\hline $\begin{array}{l}\text { Number of Expected } \\
\text { Landslides }\end{array}$ & \multicolumn{1}{|c|}{32.263} & 37.737 \\
\hline $\begin{array}{l}\text { Number of Observed } \\
\text { Landslides }\end{array}$ & \multicolumn{1}{|c|}{45} & 25 \\
\hline \multicolumn{2}{|l|}{} \\
\hline Chi-Square Calculation for Landslides and Colluvium \\
\hline & $\begin{array}{l}\text { Degrees of } \\
\text { Freedom }\end{array}$ \\
\cline { 2 - 3 } & Chi-square value & 1 \\
\cline { 2 - 3 } & Significance level & 0.72 \\
\cline { 2 - 3 } & Critical Value & 0.005 \\
\cline { 2 - 3 } & Null Hypothesis & 7.879 \\
\cline { 2 - 3 } & Reject \\
\hline
\end{tabular}

Table 6: Chi-square goodness of fit table for landslide locations compared to colluvium. The null hypothesis that landslide locations were random with respect to mine spoil could be rejected at a 99.5\% confidence level. As expected, July 2001 landslides preferentially initiated in colluvium. 


\begin{tabular}{|l|l|c|}
\hline & \multicolumn{1}{|c|}{$\begin{array}{c}\text { Transportation } \\
\text { Network }\end{array}$} & $\begin{array}{c}\text { Non-transportation } \\
\text { Network }\end{array}$ \\
\hline \multirow{2}{*}{$\begin{array}{l}\text { Number of Expected } \\
\text { Landslides }\end{array}$} & \multicolumn{1}{|c|}{4.08} & 65.919 \\
\hline \multirow{3}{*}{$\begin{array}{l}\text { Number of Observed } \\
\text { Landslides }\end{array}$} & \multicolumn{1}{|c|}{46} & \\
\hline \multirow{5}{*}{ Chi-Square Calculation for Landslides and Mine boundaries } \\
\hline & $\begin{array}{l}\text { Degrees of } \\
\text { Freedom }\end{array}$ \\
\cline { 2 - 3 } & Chi-square value & 456.66 \\
\cline { 2 - 3 } & Significance level & 0.005 \\
\cline { 2 - 3 } & Critical Value & 7.879 \\
\cline { 2 - 3 } & Null Hypothesis & Strongly Reject \\
\cline { 2 - 3 } \\
\cline { 2 - 3 }
\end{tabular}

Table 7: Chi-square goodness of fit table for landslides associated with transportation networks within Lower New River Gorge. The null hypothesis that landslide locations were random with respect to transportation networks could be strongly rejected at a 99.5\% confidence level. The strongest relationship between landslide initiation and surficial geology was the positive association with transportation networks.

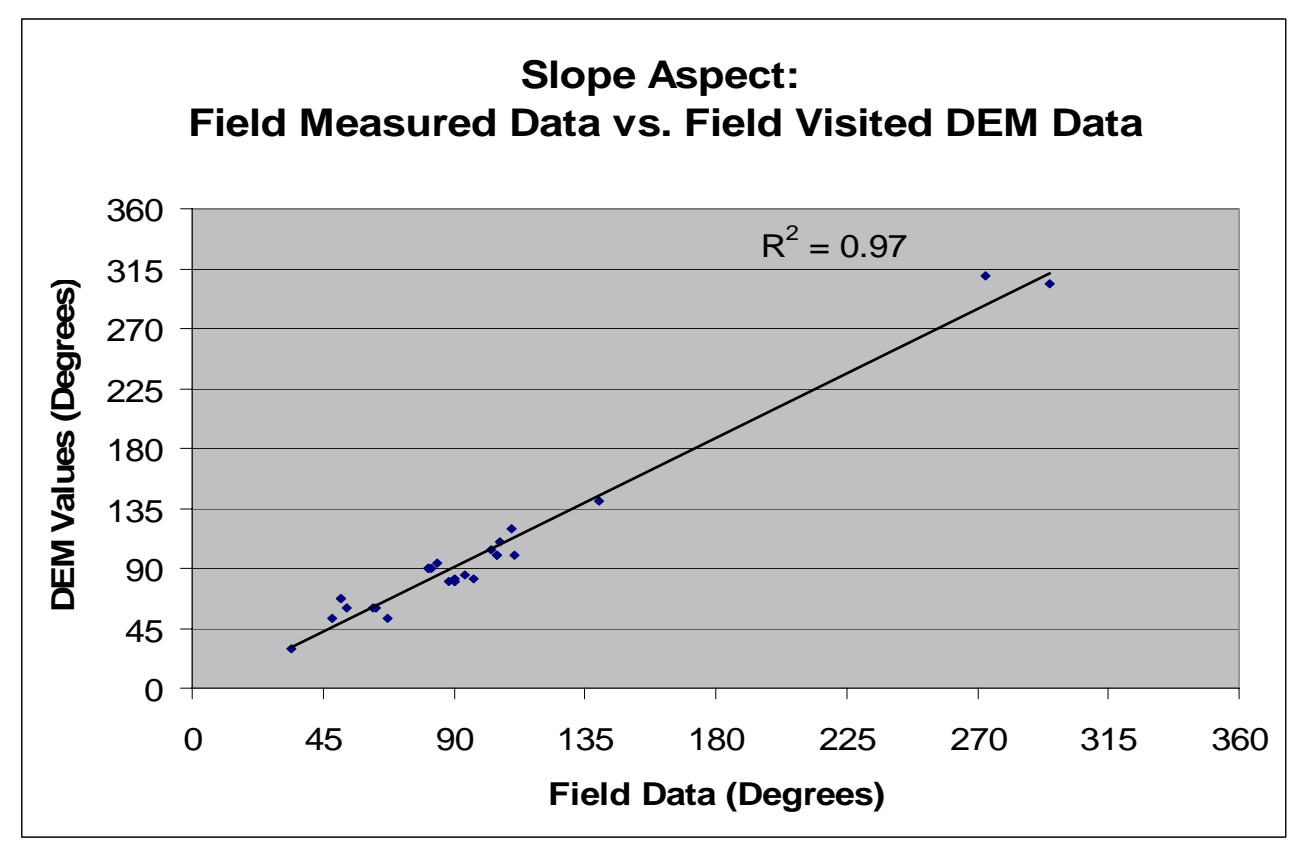

Figure 7: Field measured slope aspect data plotted against DEM derived slope aspect data. A linear regression has a coefficient of determination $\left(R^{2}\right)$ of 0.97 which shows a strong relationship between field measured data and DEM derived data for the same points allowing DEM derived slope aspects for all landslides to be used in further statistical analyses. 


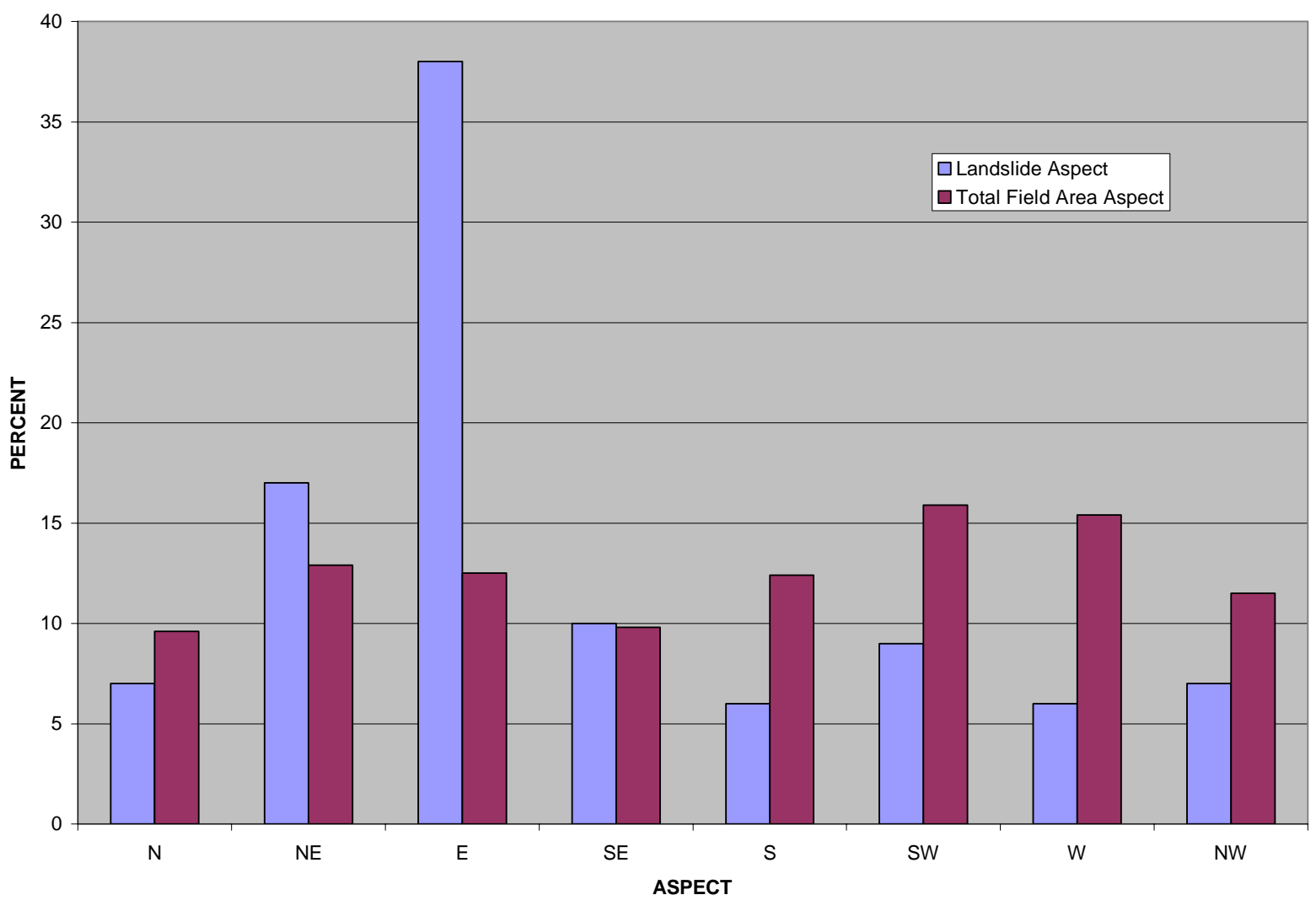

Figure 8: Histogram comparing slope aspect of all July 2001 landslides to all slope aspects for the study area. The percentage of landslides occurring on east or northeast-facing slopes outweighed the percentage of east and northeast-facing slopes in the study area. 
which characterize 38 percent of the landslides.

The DEM for the study area is composed of 419,986 pixels that represent $100 \mathrm{~m}^{2}$ each. Each pixel and its neighbors relate information about slope angle, slope aspect, and elevation. To find out if the preferential slope aspect of landslides could be explained, a chi-square goodness of fit test (Weimer, 1993) was run with a null hypothesis that the percentage of slope aspects for landslide locations was significantly different than the percentage of slope aspects for the entire study area (Table 8). This test compared the observed landslide slope aspects to the expected landslide aspects. The expected landslide aspects were derived by generating aspects for every pixel within the study area. When the expected aspects were compared to the observed aspects, the null hypothesis was rejected at a significance level of 0.005 . That is, at a $99.5 \%$ confidence level, landslide locations were not randomly distributed with respect to slope aspect. Northeast and east facing slopes were the only two aspects that favored slope failure whereas other aspects were under-represented (Figure 8).

\section{Slope Angles}

A total of four separate slope angles were measured and recorded during field visits to landslide locations. Slope angles above and below the landslide were measured along with angles of both side, adjacent slopes. These measurements were averaged to get a single slope angle value for each field visited landslide in an attempt to reproduce the same method used by ArcGIS when calculating slope angles from the DEM. The DEM generated slope angles were calculated by averaging the by averaging The mean of the field-measured slope angles were statistically compared to the mean of the DEMgenerated slope angles for the same landslide position using an independent two-sample t-test (Weimer, 1993). The calculated t-value was 0.43 and the critical value was 2.79, so the null hypothesis that both the field measured slopes and the DEM generated slopes angles were both drawn from the same population was accepted at significance level of 0.005 (Table 9).

To justify using DEM generated slope data for un-visited landslides, the unvisited DEM slope angles were statistically tested to see if they were a different population than field visited DEM generated slope values. The mean slope angles for the 


\begin{tabular}{|l|c|c|c|c|c|c|c|c|}
\hline $\begin{array}{c}\text { Aspect } \\
\text { (Degrees) }\end{array}$ & $\begin{array}{c}\text { North } \\
\mathbf{( 3 3 7 . 5 - 2 2 . 5 )}\end{array}$ & $\begin{array}{l}\text { Northeast } \\
\mathbf{( 2 2 . 5 - 6 7 . 5 )}\end{array}$ & $\begin{array}{l}\text { East } \\
\mathbf{( 6 7 . 5 -} \\
\mathbf{1 1 2 . 5 )}\end{array}$ & $\begin{array}{l}\text { Southeast } \\
\mathbf{( 1 1 2 . 5 -} \\
\mathbf{1 5 7 . 5 )}\end{array}$ & $\begin{array}{l}\text { South } \\
\mathbf{( 1 5 7 . 5 -} \\
\mathbf{2 0 2 . 5 )}\end{array}$ & $\begin{array}{l}\text { Southwes } \\
\mathbf{t} \text { (202.5- } \\
\mathbf{2 4 7 . 5 )}\end{array}$ & $\begin{array}{l}\text { West } \\
\mathbf{( 2 4 7 . 5 -} \\
\mathbf{2 9 2 . 5}\end{array}$ & $\begin{array}{l}\text { Northwest } \\
\mathbf{( 2 9 2 . 5 -} \\
\mathbf{3 3 7 . 5}\end{array}$ \\
\hline $\begin{array}{l}\text { Expected Slope } \\
\text { Aspect }\end{array}$ & 6.72 & 9.03 & 8.75 & 6.86 & 8.68 & 11.13 & 10.78 & 8.05 \\
\hline $\begin{array}{l}\text { Observed Slope } \\
\text { Aspect }\end{array}$ & 5 & 12 & 27 & 7 & 4 & 6 & 4 & 5 \\
\hline
\end{tabular}

Chi-square calculation for landslide location and slope aspect

\begin{tabular}{|l|c|}
$\begin{array}{l}\text { Degrees of } \\
\text { Freedom }\end{array}$ & 7 \\
\hline $\begin{array}{l}\text { Chi-square } \\
\text { value }\end{array}$ & 48.6 \\
\hline $\begin{array}{l}\text { Significance } \\
\text { level }\end{array}$ & 0.005 \\
\hline $\begin{array}{l}\text { Critical } \\
\text { Value }\end{array}$ & 20.28 \\
\hline $\begin{array}{l}\text { Null } \\
\text { Hypothesis }\end{array}$ & Reject \\
\hline
\end{tabular}

Table 8: Chi-square goodness of fit table for landslide slope aspect compared to overall aspects in study area. The null hypothesis that landslides occurred in a random fashion compared to slope aspect was rejected at a confidence level of 99.5\%. This result indicates that east-facing slopes favored landslide initiation during July 2001. 


\begin{tabular}{|l|c|c|c|}
\hline & Mean & $\begin{array}{c}\text { Standard } \\
\text { deviation }\end{array}$ & n-values \\
\hline Field Visited Neighboring Slope Angles (DEM) & 28.1 & 9.4 & 24 \\
\hline $\begin{array}{l}\text { Field Visited Neighboring Slope Angles (average } \\
\text { of field data) }\end{array}$ & 30.5 & 9.3 & 24 \\
\hline \multicolumn{2}{|c|}{$\begin{array}{c}\text { t- } \\
\text { value }\end{array}$} & $\begin{array}{c}\text { Critical } \\
\text { Value }\end{array}$ & Result \\
\hline Field Visited slides (DEM vs. Field data) & 0.43 & 2.79 & $\begin{array}{c}\text { Cannot reject null } \\
\text { hypothesis }\end{array}$ \\
\hline
\end{tabular}

Table 9: Table showing comparison of field measured slopes to DEM generated slopes

for same locations. The null hypothesis that DEM derived and field-measured slopes angles associated with the landslides were drawn from the same population could not be rejected. These results indicate that DEM generated slope angles for field visited landslides could be used for statistical analysis. 
field visited DEM generated slopes were compared to the mean of the un-visited landslide slope angles generated by DEM (Table 10) and a two-sample t-test was used for comparison. The null hypothesis for the two-sample t-test was that the two sets of slope angles were drawn from the same population. The calculated t-value was 1.00 and the critical value was 2.79, so the null hypothesis was accepted at a significance level of 0.005. These tests indicated that the DEM values for all 70 landslides could be used for statistical comparison with the DEM generated slope angles for the study area.

When DEM-derived slope values for both landslides and the whole study area were compared statistically using the two-sample t-test, it was determined that the slope angles were derived from two different populations at a significance level of 0.005, with a t-value of 11.28 and critical value of 2.64 (Table 11). The analysis indicates that landslide slope angles (mean $=28.5$ degrees) differ from slope angles derived for the whole study area (mean $=24.1$ degrees).

Over-representation of slope angles associated with DEM measured landslides occurs within the $15^{\circ}-25^{\circ}$ range. This may be the preferred slope angles for road building which has resulted in unstable undercut slopes and perched fill material. An obvious spike in the percentage of DEM generated landslide slope angles and field measured slope angles compared to total study area slope angles occurred in the $35^{\circ}-50^{\circ}$ range, which most likely represents the increased role of physical factors, such as gravity and friction, on slope stability (Figure 9). The general lack of landslides in the $55^{\circ}-70^{\circ}$ range may reflect the presence of resistant bedrock outcrops (Figure 9).

\section{Elevation}

Elevation data was not collected at landslide locations visited in the field due to poor vertical accuracy of the 12 channel handheld GPS units. All elevation data used in landslide elevation analyses were derived from DEM. Landslide location elevations were grouped in $20 \mathrm{~m}$ increments and compared to all DEM generated elevations using the chisquare goodness of fit test (Table 12). The null hypothesis that landslide elevations are random compared to all study area elevations was rejected with a calculated chi-square value of 88.05 and critical value of 39.99 (Table 12). At a 99.5\% confidence level, landslide elevations were not random. 


\begin{tabular}{|l|c|c|c|}
\hline & Mean & Standard deviation & n-values \\
\hline $\begin{array}{l}\text { Field Visited Neighboring Slope Angles } \\
\text { (DEM) }\end{array}$ & 28.1 & 9.4 & 24 \\
\hline $\begin{array}{l}\text { Non-field Visited Slides Neighboring } \\
\text { Slope Angles (DEM) }\end{array}$ & 28.9 & 12.0 & 46 \\
\hline \multicolumn{2}{|c|}{ Critical Value } & Result \\
\hline $\begin{array}{c}\text { DEM Slope Angles (Field visited vs. } \\
\text { Non-field visited) }\end{array}$ & 1 & 2.79 & $\begin{array}{c}\text { Cannot reject null } \\
\text { hypothesis }\end{array}$ \\
\hline
\end{tabular}

Table 10: Table showing DEM generated slope angles for field visited landslides locations compared to DEM generated slope angles for un-visited landslides. The null hypothesis was rejected indicating that the two sets of slope angles are statistically similar and could be represented as a single population in analysis.

\begin{tabular}{|c|c|c|c|}
\hline & Mean & $\begin{array}{l}\text { Standard } \\
\text { deviation }\end{array}$ & n-values \\
\hline All Slide Slope Angles (DEM) & 28.5 & 10.9 & 70 \\
\hline All Study area Slope Angles (DEM) & 24.1 & 12.9 & 419986 \\
\hline & t-value & Critical Value & Result \\
\hline $\begin{array}{c}\text { All Slide Slope angles vs. All Study area Slopes } \\
\text { Angles (DEM) }\end{array}$ & 11.28 & 2.64 & $\begin{array}{l}\text { Strongly rejec } \\
\text { null hypothesi }\end{array}$ \\
\hline
\end{tabular}

Table 11: DEM generated slope angles for all landslides compared to DEM generated slope angles for all study area. The null hypothesis was rejected indicating that the higher mean slope angles associated with the landslides are preferential to slope failure. 


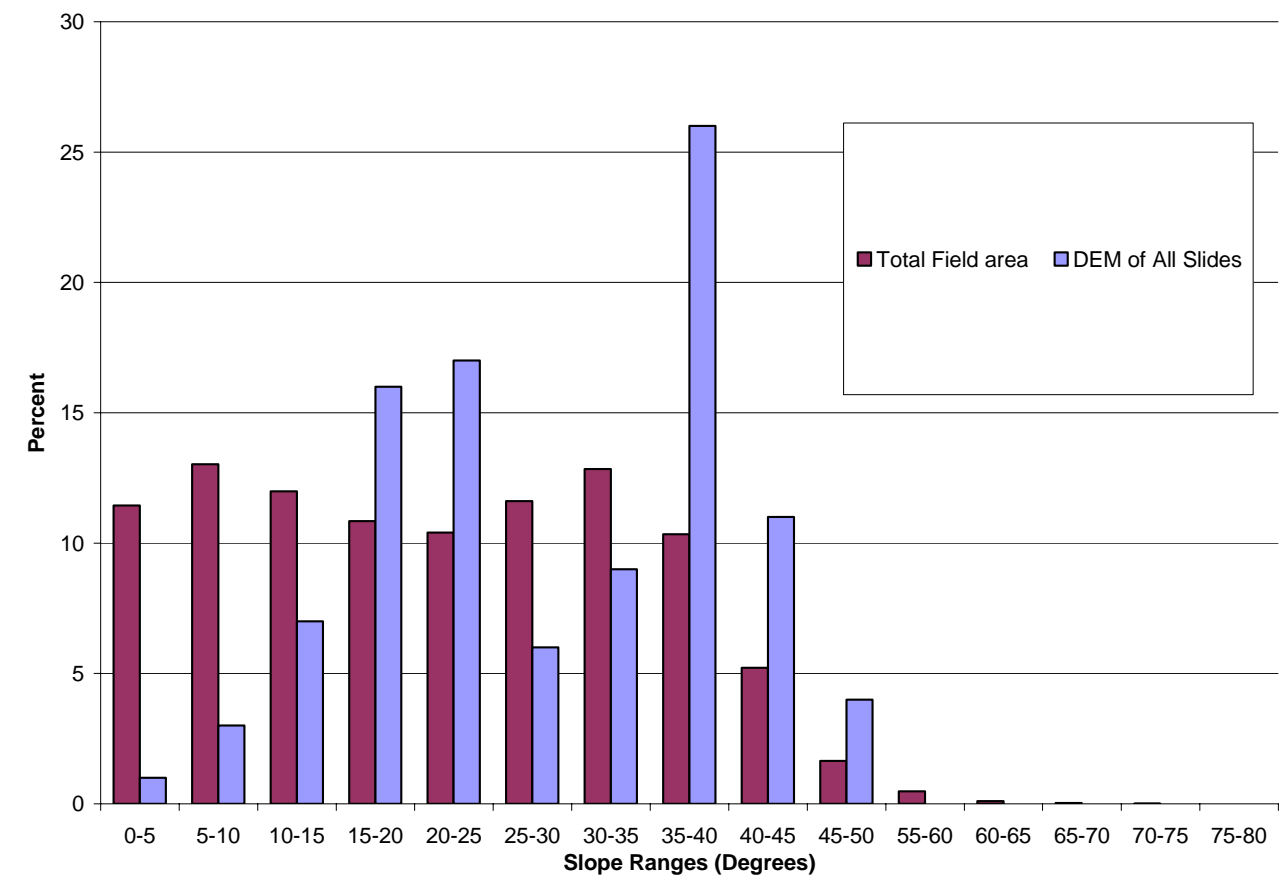

Figure 9: DEM generated slope angles for landslides compared to total study area and field measured adjacent slope angles. A spike in landslides in the 35-50 degree range most likely results from the increased role of physical factors, such as the angle of repose for bouldery, colluvial soils, on slope stability. 


\begin{tabular}{|c|c|c|c|c|c|c|c|c|c|c|c|c|c|c|c|c|c|c|c|c|c|}
\hline & 250 & 270 & 290 & 310 & 330 & 350 & 370 & 390 & 410 & 430 & 450 & 470 & 490 & 510 & 530 & 550 & 570 & 590 & 610 & 630 & 650 \\
\hline $\begin{array}{l}\text { Expected number of } \\
\text { landslides }\end{array}$ & 0.7 & 2.1 & 4.2 & 4.2 & 2.8 & 2.8 & 2.8 & 2.8 & 2.8 & 2.8 & 2.8 & 2.8 & 2.8 & 3.5 & 4.2 & 5.6 & 6.3 & 7 & 5.6 & 1.4 & 0 \\
\hline $\begin{array}{l}\text { Observed number of } \\
\text { landslides }\end{array}$ & 0 & 0 & 5 & 8 & 6 & 3 & 5 & 0 & 4 & 9 & 11 & 7 & 6 & 3 & 1 & 2 & 0 & 0 & 0 & 0 & 0 \\
\hline \multicolumn{3}{|c|}{$\begin{array}{l}\text { Chi-square calculation for landslide location and } \\
\text { elevation (20 m increments) }\end{array}$} & & & & & & & & & & & & & & & & & & & \\
\hline & $\begin{array}{l}\text { Degrees of } \\
\text { Freedom }\end{array}$ & 19 & & & & & & & & & & & & & & & & & & & \\
\hline & Chi-square value & 88.05 & & & & & & & & & & & & & & & & & & & \\
\hline & Significance level & 0.005 & & & & & & & & & & & & & & & & & & & \\
\hline & Critical Value & 39.99 & & & & & & & & & & & & & & & & & & & \\
\hline & Null Hypothesis & reject & & & & & & & & & & & & & & & & & & & \\
\hline
\end{tabular}

Table 12: Chi-square goodness of fit table for landslide elevations and total study area elevations subdivided into $20 \mathrm{~m}$ increments. The null hypothesis that landslide elevations were random could be rejected with $99.5 \%$ confidence. The July 2001 landslides appear to have initiated in preferred elevations that are related to road locations along the Sewell coal seam. 
After it was determined that the landslide elevations were not randomly distributed in 20 $\mathrm{m}$ increments, an attempt was made to determine which elevation ranges in the gorge favor landslide initiation. Study area elevations were broken down into four $100 \mathrm{~m}$ increments and compared to the landslide elevations that fell within these increments. The chi-square goodness of fit test was used to compare all study area elevations to landslide elevations (Table 13). The null hypothesis that the landslide elevations were random compared to the study area elevations was rejected at a significance level of 0.005 , with a calculated chi-square value of 32.4 and a critical value of 12.84 (Table 13). At a 99.5\% confidence level, that there was no random association between landslide elevations and study area elevations for $100 \mathrm{~m}$ increments.

\section{Area vs. Volume and Slope Geometry}

Total areas for the 34 landslides visited ranged from $10 \mathrm{~m}^{2}$ to $9000 \mathrm{~m}^{2}$; estimated landslide volumes ranged from $10 \mathrm{~m}^{3}$ to $45000 \mathrm{~m}^{3}$. An area-volume scatterplot (Figure 10) showed a $0.997 r^{2}$ value for the best fit line indicating very strong linear relationship between the area and volume for the field visited landslides further indicating that volume could be used a proxy for area in further statistical analyses.

The morphology of New River Gorge slopes is divided into three major classes:

1. Nose (convex) slopes

2. Hillside hollow (concave) slopes

3. Planar (flat) slopes

Hillside hollows within the Gorge produced most (63\%) landslides, compared to nose slopes (13\%) and planar slopes (24\%). Landslide area and volume relationships vary in strength for the three slope geometries (Figure 11). The two largest landslides, Elverton and Cunard, were not included in the area-volume plot because these large slides extended over multiple slope geometries. Nose slopes had the strongest areavolume linear relationship, with an $r^{2}$ value of 0.935 , indicating that the soil depths associated with nose slopes failures varied the least out of the 3 types of slope geometries. Planar slopes showed a slightly higher variation of area-volume, with an $\mathrm{r}^{2}$ value of 0.893 . The hillslope hollow geometry had the weakest linear area-volume relationship with an $r^{2}$ value of 0.642 . The low correlation of area-volume may indicate 


\begin{tabular}{|c|c|c|c|c|}
\hline Landslide elevations & $250-350 m$ & $350-450 m$ & $450-550 m$ & $550-650 m$ \\
\hline expected & 14 & 14 & 16.1 & 25.9 \\
\hline observed & 19 & 21 & 28 & 2 \\
\hline & Degrees of Freedom & 3 & & \\
\hline & Chi-square value & 32.4 & & \\
\hline & Significance level & 0.005 & & \\
\hline & Critical Value & 12.84 & & \\
\hline & Null Hypothesis & Reject & & \\
\hline
\end{tabular}

Table 13: The chi-square goodness of fit test for landslide elevations and total study area elevations subdivided into 100m increments resulted in the rejection of the null hypothesis. The 2001 landslides in Lower New River Gorge initiated at preferred elevations, possibly as a result of road building and mining. The low number of landslides at higher elevations possibly result from the flatter slopes found at the $550 \mathrm{~m}$ $650 \mathrm{~m}$ elevation range.

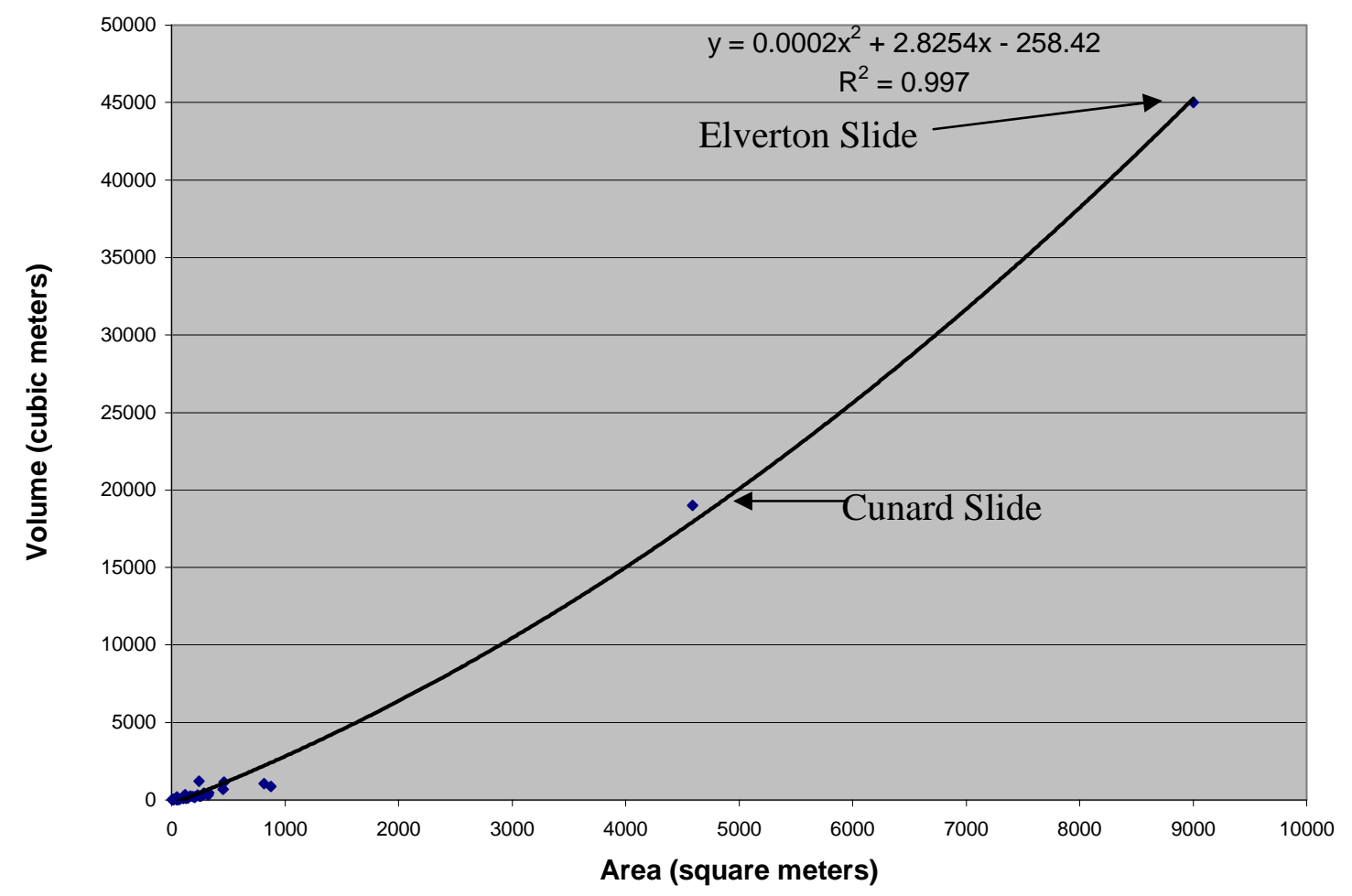

Figure 10: $X-Y$ scatter plot showing landslide area versus landslide volume. The slope value of 0.997 indicates that there is a strong relationship between area and volume for the July 2001 landslides in Lower New River Gorge. The results indicated landslide areas can be used as a proxy for landslide volume in analyses. 


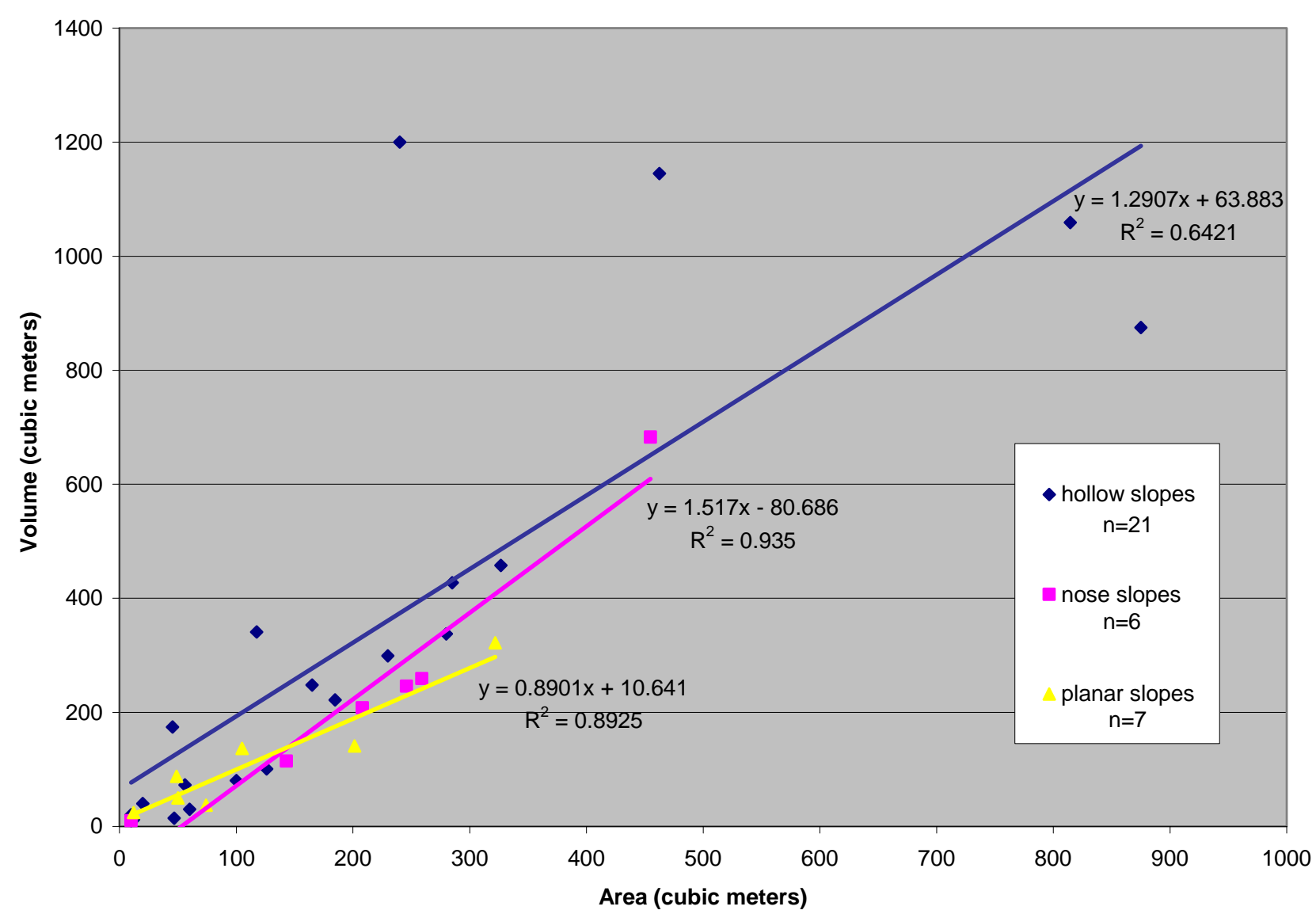

Figure 11: $\mathrm{X}-\mathrm{Y}$ plots showing landslide area versus landslide volume segregated by slope geometry. $\mathrm{R}^{2}$ values indicate nose slopes had the least volume/area variability, whereas hollow slopes had the largest variability 
the varying degree to which hillslope hollows were filled with natural or artificial material.

\section{Landslide Hazard Map}

Selected factors were combined to create a 1:15,000 scale landslide-initiation and runout risk map using the Spatial Analyst extension in ArcGIS 8.3 (Plate 2). The physical factors used in delineating landslide hazard risk were

- transportation networks

- $\quad$ slopes greater than $35^{\circ}$

- hillslope hollow geometry.

A GIS layer was created for each of the three factors, the layers were overlain, and relative risk levels were determined by the layer coincidence. Moderate risk areas occur where any two factors were encountered. High risk areas occur where hillslope hollows coincide with transportation networks and slope angles greater than $35^{\circ}$. Major hillslope hollows were delineated as possible runout paths (concave areas that act to funnel downslope moving material)(Plate 2).

\section{Summary:}

Several factors of New River Gorge play roles in landslide initiation during high precipitation events. Surficial geology of the gorge played a statistically significant role in initiation of the 2001 mass movements. Slope aspect, slope angles, and elevation were also shown to have strong relationships with landslide initiation.

Alluvium units were statistically shown not to favor landslide initiation. The depositional environment and lowland distribution of alluvium explain the lack of landslides. Relatively low slope angles are required for alluvial deposition, reducing the risk of downslope movement, especially in coarse grained alluvium.

Mine spoil and transportation networks are management-related surficial geology units that appeared to play a statistically significant role in landslides. Landslides tend to initiate on steep slopes with heterogeneous material (such as mine spoil) and high pore pressure (Baroni et al., 2000). Increase of pore pressure can result from high-intensity rainfall similar to the July 2001 events coupled with a downslope decrease in hydraulic 
conductivity in soil and bedrock as a result of compacted road fill material (Reid et al., 1988).

Transportation networks were associated with more than half of the 45 landslides (Plate 1). The heavily mined Sewell coal seam has a nearly continuous road network connecting its various mines within the gorge. Road building techniques consisted of cutting into the steep hillsides and using the excavated material to make a nearly level road surface perched on the steep slopes of the gorge. The road-fill material generally consists of the same constituents as surface mine spoil and created the same landslideprone conditions, including high pore pressure during high intensity precipitation events. Transportation networks not only resulted in destabilization of slopes, but the slopes above the roads were destabilized because of vertical to near-vertical road cuts where colluvial toeslopes of hillsides were excavated, resulting in an increased probability of failure.

Slope aspect was shown to play a statistically significant role in landslide initiation. Thirty-eight percent of landslides occurred on east-facing slopes (while the remaining sixty-two percent of landslides were divided up among the remaining seven slope aspect categories). A possible explanation for the high percentage of landslides on east-facing slopes is that most mined areas and transportation networks occur on the western side of the gorge, resulting in east facing slopes.

Statistical analysis showed certain slope angles ranges are associated with more landslides than others. Statistical analysis shows that the mean slope angles associated with the landslides were different from the mean slope angles for the entire study area. Not surprisingly, the largest percentage of landslides occurred at slope angles ranging from $35^{\circ}-50^{\circ}$ (Figure 9). Adjacent slope angles associated with the field visited sites where plotted next to the DEM generated values for those sites indicate poor correlation between the two data sets (Figure 12). Although the overall DEM generated landslide slope angles were shown to be statistically similar to the field visited landslide slope angles, further statistical work comparing DEM generated slope data and actual field measured data is suggested.

Landslide occurrence also clustered around certain elevations in the gorge. There are two prominent ranges associated with the most landslide occurrence, 300 to $380 \mathrm{~m}$ and 


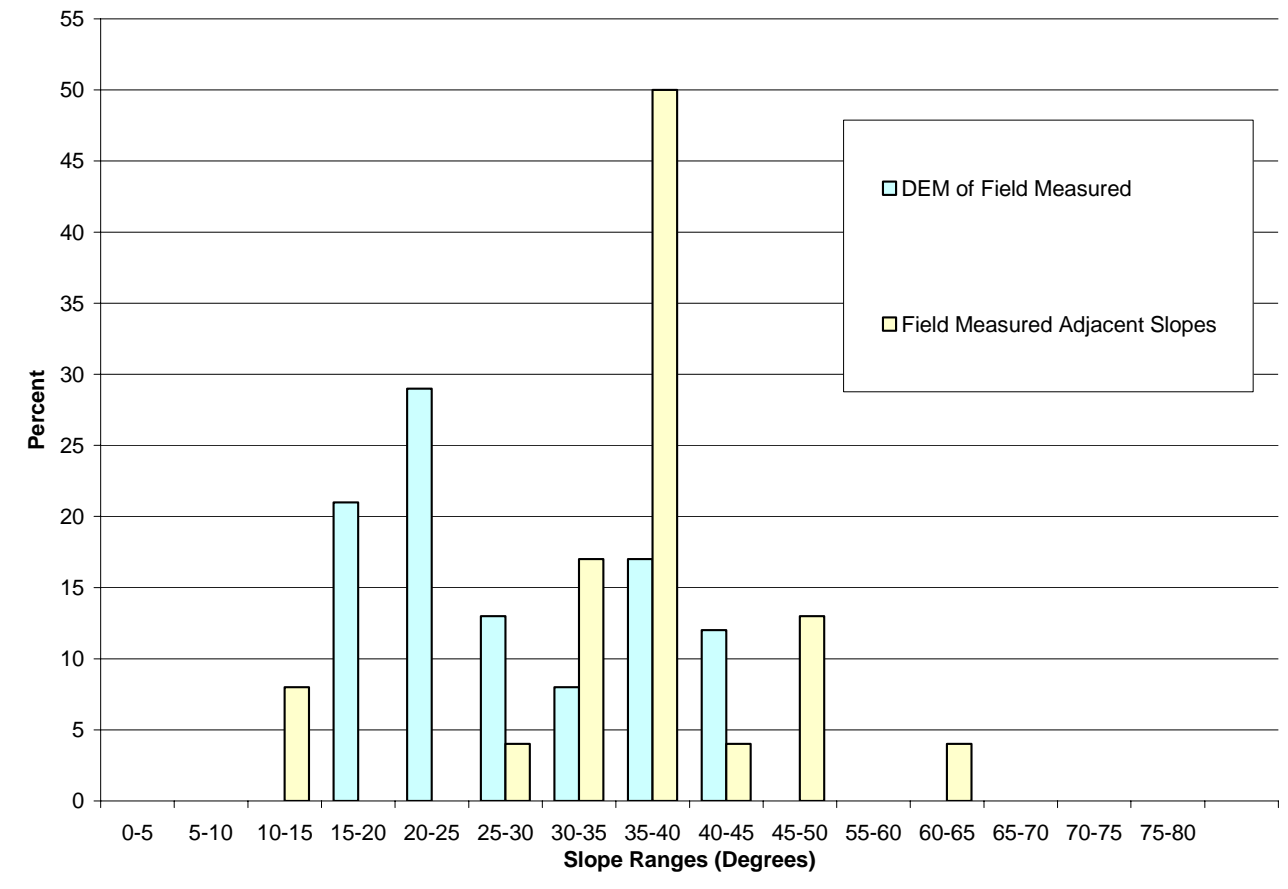

Figure 12: DEM field measured slopes compared to field measured adjacent slopes. Future work comparing DEM generated slope angles and field measured slope angle is suggested as a result of the lack of correlation between these two data sets. 
420 to $500 \mathrm{~m}$. These clusters may be the result of road building which is found at these elevations in the gorge.

The slope geometry at the landslide initiation points had different effects on the number of landslides and the area-volume relationships for the landslides (Figure11). Planar slopes had low area-volume correlation values that indicated a relatively low variability of soil depth across planar slopes. Nose slopes make up the lowest percentage of landslides (13\%) and have the closest linear relationship of area vs. volume which indicated the lack of variability with respect to soil depth in nose slope areas. This results in a lack of surface and ground water buildup that is not conducive to landsliding. Most landslides (63\%) occurred within hillslope hollows that concentrate both unconsolidated material and water which were favorable conditions for landslide initiation.

\section{Discussion:}

The lack of understanding of geomorphologic factors controlling landslides has resulted in property damage and loss of life in West Virginia in the past. The cost of park rehabilitation due to the July 2001 rain events was estimated to be over \$6.5 million dollars (National Park Resource Assessment Team, 2001). Most landslides resulting from the July 2001 events developed in historically disturbed areas. This study has shown that landslides in New River Gorge have several preferential physical factors associated with their initiation that are commonly associated with slope failures throughout the Appalachian region and elsewhere.

The role of high precipitation on the steep slopes of the Appalachian region and nearby areas has been documented over the past 50 years. Central Virginia received a maximum of $710 \mathrm{~mm}$ of rain as a result of Hurricane Camille in 1969 and suffered loss of lives due to flash flooding and landslides (Williams and Guy, 1973). In 1977, a storm system responsible for debris avalanching in the steep terrain of the Pisgah National Forest, North Carolina produced 200-340 mm of rainfall (Neary and Swift, 1987). The November 1985 storm that affected West Virginia and Virginia delivered more than 220 $\mathrm{mm}$ to a widespread area (Colucci, et al., 1993). Devastating debris flows and floods in Madison County, Virginia resulted from a series of high precipitation events in June 1995. The area received a maximum of $770 \mathrm{~mm}$ of total precipitation at rates as high as $300 \mathrm{~mm} / \mathrm{h}$ (Wieczorek et al., 2000). The debris flows that resulted from the 1995 rainfall 
initiated when local rainfall exceeded 50 to $100 \mathrm{~mm} / \mathrm{h}$, a threshold that was not met during the July 8 rainfall event..

Several principles for the occurrence of debris flows in the central and southern Appalachians suggested by Wieczorek et al. (2000) can be applied to New River Gorge. Steep slopes combined with continuous high intensity rainfall form suitable conditions for slope failures throughout the Appalachian region but when compared to other landslide inducing storm events in the region, the July 2001 storm generally had lower rainfall totals (100- $280 \mathrm{~mm}$ ). Mine spoil and areas affected by building of transportation networks fail at much lower precipitation thresholds than natural landslides in lower New River Gorge.

Several factors controlling the July 2001 landslides are related to the human influences on slopes of New River Gorge. Road building and mining resulted in oversteepened slopes and perched unconsolidated fill material on already steep slopes. The results of this study agree with Montgomery (1994), who indicated that disturbed slopes as a result of road building have much higher rates of erosion than undisturbed slopes. Road building and mining also remove well established vegetation rooting systems that act to anchor colluvial material to hillslopes (Riestenberg, 1993).

Landslide inducing events may only have a recurrence interval of once two thousand years for the same area, but the landslide events happen on the scale of once every three years somewhere in the central and southern Appalachians (Wieczorek et al., 2000). A better understanding of the dynamic interaction of the factors involved with the landslides that occur in the Appalachian region would allow federal, state, and private landowners to make better land management decisions. An example of how the information derived from the July 2001 landslide study may help in the future can be seen on Plate 2, where factors determined to be statistically significant in landslide intitation were combined to indicate areas of moderate and high risk. Maps similar to this can be used to avert financially unsound decisions pertaining to trail or road repair issues. More importantly, possible life-threatening issues below some of the high risk areas may be identified before another such storm event. 


\section{Future research:}

Future research dealing with landslides in New River Gorge is suggested. The role of very detailed rainfall intensity and total thresholds related to landsliding in the gorge would be valuable. Without rainfall gauges and flow stations in the immediate study area rainfall variations could not be analyzed. Thresholds could be used as early warning indicators for possible closures or evacuations of areas in the immediate proximity during high intensity events. Sirens and warning signs may help informing the public of hazardous conditions. The installation of rainfall gauges and flow stations in areas of high risk to landsliding could be instrumental in determining optimum meteorological conditions for slope failures but could be costly.

The role of vegetation and its effect on slope stability would be another valuable concept to understand. Field identification and multi-spectral imaging of plant species in landslide prone areas may identify a relationship between vegetation types and landslides. It would be of great value to identify plant species that can stabilize slopes, as a result of dramatic increases in root strength. Such plants could then be used for remediation or precautionary measures in areas prone to slope failures within the gorge.

Future work should be done on the anthropogenic soil associated with landslide prone areas including textural and mineralogical analyses. The understanding of management related soil variations may help in the further delineation of landslide prone areas in the gorge. Certain soils may be identified as unstable soils and sampling and laboratory analyses may give some indication of which soil forming factors are conducive to landsliding. Local bedrock changes may play a large part in determining the physical characteristics of anthropogenic soils and it is suggested that this idea be investigated further.

The presence of disrupted watercourses and an assessment of their role in slope failures is suggested for future research. Disrupted watercourses may result in a concentration of water in unstable areas during periods of high precipitation. Fieldwork and the most recent aerial photography could be used to locate disrupted watercourses. These areas could then be mapped and various spatial analyses could be performed on their physical characteristics. 


\section{References Cited}

Baroni, C., Bruschi, G., and Ribolini, A., 1999, Human-induced hazardous debris flows in Carrara Marble Basins (Tuscany, Italy): Earth Surface Processes and Landforms, v. 25, p. 93-103.

Cambell, R., H., , Varnes, D., J., Fleming, R., W., Hampton, A., Prior, D., B., Sangrey, D., B., Dwight, A., Nichols, D., R., and Brabb, E., 1985, Landslide classification for identification of mudflows and other landslides, in Cambell, R., H., editor, Feasibility of a nationwide program for the identification and delineation of hazards from mud flows and other landslides: U.S. Geological Survey Open-File Report 85-276, p. A1-A24.

Colucci, S. J., Jacobson, R. B., and Greco, S., 1993, Meteorology of the Storm of November 3-5, 1985, in West Virginia and Virginia: in Jacobson, R., B., editor, Geomorphic studies of the storm and flood of November 3-5, 1985, in the Upper Potomac and Cheat River basins in West Virginia and Virginia: U.S. Geological Survey Bulletin 1981, B1- B31.

Englund, K.J., King, E.R., Lesure, F.G., and Perry, W.J., Jr., 1977, Mineral resource, geological, and geophysical maps of the New River Gorge area, Fayette, Raleigh, and Summers counties, West Virginia: U.S. Geologic Survey Open-File Report 77-076, 12 sheets, 26 maps.

Englund, K.J., Johnson, P.L., and Arndt, H.H., 1982, Geology of the New River Gorge, West Virginia: New River Symposium Proceedings, May 6-8, 1982, Beckley, West Virginia, p. 136-145.

Gorman, J.L., and Espy, L. E., 1975, Soil Survey of Fayette and Raleigh Counties, West Virginia: U. S. Department of Agriculture, Soil Conservation Service, in cooperation with West Virginia University Agricultural Experiment Station, 76 p., 120 sheets.

Hack, J. T., and Goodlett, J. C., 1960, Geomorphology and forest ecology of a mountain region in the central Appalachians: U.S. Geological Survey Professional Paper 347, 66p.

Hungr, O., Evans, S.G., Bovis, M.J., and Hutchinson, J.N., 2001, A review of the classification of landslides of the flow type: Environmental and Engineering Geoscience, v. 7, no. 3, p. 221-238.

Jenkins, T., Patrick Kish phone conversation with Natural Resources Conservation Service Soil Scientist, November 2002. 
Kite, J. S., 2001, Guidelines for Preparation of Surficial Geology Quadrangle Maps for West Virginia and Adjacent States. West Virginia University Department of Geology and Geography, Morgantown, West Virginia, Working Document, 2001.

Kite, J. S., Unpublished data collected on various dates in 2001-2002.

Kochel, R. Craig, 1987, Holocene debris flows in central Virginia, in Costa, J.E., and Wieczorek, G.F., Debris Flows/Avalanches: Processes, Recognition, and Mitigation: Geological Society of America Reviews in Engineering Geology Volume VII, P. 139-155.

Kwak, B. J., 2002, Reconnaissance of Geologic and Coal Mining Controls of Slope Failures on the Cunard to Kaymoor Trail, Elverton, New River Gorge, Fayette County, West Virginia: Professional Studies M.S. Project Report, Morgantown, West Virginia University, 35 p.

Lane, R., and Schenpf, T., 1999, West Virginia Narrow Gauge, Mann’s Creek Railway: TLC Publishing Inc., Lynchburg, VA, 202 p.

Montgomery, D. R., 1994, Road surface drainage, channel initiation and slope instability, Water Resources Research, v. 30, no. 6, p. 1925-1932.

Moore, D., 1999, The Origin of Rapids in the Lower New River Gorge, West Virginia: M.S. Thesis, Morgantown, West Virginia University, 60 p.

Morgan, J. T., and Mayfield, M. W., 1994, The oldest river in the world?: Southeastern Geographer, v. XXXIV, p. 138-144.

Mills, H.H., 1990, Geologic and topographic controls of the rapids of the New River Gorge, West Virginia: Southeastern Geology, v. 31, p. 45-62

Neary, D. G., and Swift, L. W., Jr., 1987, Rainfall thresholds for triggering a debris avalanching event in the southern Appalachian Mountains: Geological Society of America, Reviews in Engineering Geology: Geological Society of America, Boulder, Colorado, v. VII, p. 81-92.

National Oceanographic and Atmospheric Administration, 2002, Oak Hill Rain Gauge Data.

National Oceanographic and Atmospheric Administration, 2002, Storm Precipitation Imagery.

National Park Service Resource Assessment Team, 2001, New River Gorge Floods-2001: Emergency Rehabilitation Plan, Glen Jean, West Virginia, 349 p. 
Reid, M.E., Nielsen, H.P., Dreiss, S.J., 1988, Hydrologic factors triggering a shallow hillslope failure: Geological Society of America Reviews in Engineering Geology, v. 15, no. 3, p. 349-361.

Riestenberg, M. M., 1994, Anchoring of thin colluvium by roots of sugar maple and white ash on hillslopes of Cincinnati: U.S. Geological Survey Bulletin 2059-E, $25 \mathrm{p}$.

Remo, J.W.F., 1999, Geologic Controls on Mass Movement in the New River Gorge, West Virginia, M.S. Thesis: Morgantown, West Virginia University, 107 p.

Skousen, J., 2001, Reclamation of Disturbed Soils: Teacher’s Press, Morgantown, West Virginia, 337 p.

Steele, A., 2003, Patrick Kish phone conversation with National Park Service GIS Analyst, May 2003.

Ward, S. M., Taylor, B. C., and Crosby, G. R., 1999, Water Resources Data, West Virginia, Water Year 1998: U.S. Geological Survey Water-Data Report WV-98-1, 476 p.

Weimer, R., 1993, Statistics: William C. Brown Publishing, Dubuque, IA, 777p.

Wieczorek, G. F., 1987, Effect of rainfall intensity and duration on debris flows in central Santa Cruz Mountains, California, in Costa, J. E. and Wieczorek, G. F. Editors, Debris Flows, Avalanches: Process, Recognition, and Mitigation: Geological Society of America, Reviews in Engineering Geology: Geological Society of America, Boulder, Colorado, v. 7, p. 93-104.

Wieczorek, G. F., Morgan, B. A., and Campbell, R. H., 2000, Debris-Flow hazards in the Blue Ridge of Central Virginia: Environmental and Engineering Geoscience, v. VI, no.1, p. 3-23.

Williams, G. P., and Guy, H. P., 1973, Erosional and depositional aspects of Hurricane Camille in Virginia, 1969: Geological Survey Professional Paper 804, Geological Survey, Washington D.C., 79 p.

Yuill, C, 1988. Mine and Well Site Inventory for New River Gorge, West Virginia: West Virginia University, Morgantown, West Virginia, 882 p. 









